\title{
Imagens dos índios na Amazônia espanhola, nos séculos XVI e XVII
}

\author{
por \\ Francismar Alex Lopes de Carvalho ${ }^{1}$ \\ Universidad del Estado de Río de Janeiro, Brasil
}

Desde meados do século XVI e por todo o século XVII, colonos e missionários exploraram assiduamente as franjas da Amazônia localizadas a oriente da Audiência de Quito e teceram diversas imagens das populações indigenas. Os nativos foram classificados em duas grandes categorias: de um lado, estavam os tidos por "amigos", em quem os espanhóis verificavam certos sinais de "polícia"; de outro, os "bárbaros", geralmente retratados como nômades e antropófagos. Uma análise mais acurada dessas imagens mostra que elas se coadunavam com os objetivos específicos de colonos e missionários, vale dizer, a captura de mão de obra para o serviço pessoal e o estabelecimento de reduções.

PalaVRas-Chave: índios amigos; indios bárbaros; Amazônia; missões jesuiticas; encomienda.

Cómo Citar este artículo / Citation: Lopes de Carvalho, Francismar Alex, "Imagens dos índios na Amazônia espanhola, nos séculos XVI e XVII", Revista de Indias, LXXVIII/274 (Madrid, 2018): 687-733. https://doi.org/10.3989/revindias.2018.021.

¿Qué clase de hombres son estos? Sus comidas y condimentos crecen en los árboles que les dan, además, hilo. [...] Encuentran sus hachas en las quebradas, sus agujas en los espinos, sus cuchillos en los animales, sus joyas en los pescados y sus cuerdas en todas partes. [...] Matan y curan con su soplo. [...] ¿Qué gentes son estas? Sus vacas viven en el agua, los cerdos tienen el ombligo en la espalda, las gallinas son gallos, y otros animales tienen figuras de hombres. Hay pájaros que tienen el don de la palabra. Estos hombres habitan con las culebras, comen cocodrilos, beben lo que escupen, toman las frutas por debajo y las respiran por la

1 francismardecarvalho@gmail.com, ORCID iD: https://orcid.org/0000-0002-6172-3363. 
nariz, hacen sus casas en el aire, duermen sobre el fango, viven soñando, mueren por los sortilegios. ¿Qué son estos hombres tan singulares?

Padre Juan Magnin, S.J. ${ }^{2}$

\section{INTRODUÇÃO}

No mundo antigo, bárbaros eram aqueles que não possuíam as qualidades necessárias para ser civitas, ou seja, não partilhavam dos códigos culturais gregos ou romanos. A servidão desses homens era vista como um bem que se lhes fazia. Para Aristóteles, os bárbaros eram imutáveis, dotados pela natureza de atributos que os adequavam ao serviço de outrem, como a força física, ao passo que entre os cidadãos encontravam-se os traços que lhes facultavam a vida política. Para Cícero, em contrapartida, mesmo os bárbaros podiam ser convertidos em cidadãos. ${ }^{3}$ Desse modo, o bárbaro era compreendido sempre de modo relacional: já as descrições dos Citas oferecidas por Heródoto só cobravam sentido em sua homologia simétrica com as práticas e modos de pensar de gregos e não gregos, algo que um autor moderno chamou de "desvio sistemático". ${ }^{4}$

Em todo o caso, relatos jesuíticos e de outros cronistas das Índias dos séculos XVI e XVII estavam mais interessados em persuadir, inserindo seu enredo em uma contraposição entre vícios e virtudes, do que em produzir uma descrição realista. A história era compreendida como "mestra da vida", e os relatos visavam, antes de tudo, "ensinar a viver", de modo a permitir aos leitores identificar os vícios e virtudes encarnados nas ações dos homens. ${ }^{5} \mathrm{O}$ gênero demonstrativo, dizia o frei mexicano Diego Valadés, em sua Retórica cristiana de 1579, era aquele que objetivava inferir, a partir de qualidades exteriores e interiores, o que havia em uma pessoa digno "de alabanza y de

\footnotetext{
2 Magnin, 1998 [1740]: 202.

3 Pagden, 1988: 35-42. Raminelli, 1996: 66. Sobre como os gregos distinguiam os bárbaros e os selvagens, ver: Bartra, 1996: 22 e ss.

${ }^{4}$ Hartog, 1999: 49. Na tradição judaico-cristã, contudo, houve um deslocamento importante: conservado o sentido de inferioridade, a palavra "bárbaro" passou a designar também, e principalmente, o pagão. Por não crerem em Cristo, esses homens não se governavam de acordo com a verdadeira razão, e passavam seus dias em constantes agressões, sem observar nenhuma lei ou norma de conduta (Pagden, 1988: 42). Entre os renascentistas, contudo, houve quem valorizasse certos elementos do selvagem como contrapeso ao "artificialismo" da sociedade europeia (Bernheimer, 1970: 144-145), e na opinião de Certeau (1982: 277-278), a "invenção" do selvagem nos séculos XVI e XVII atendia à construção de um modelo pedagógico para o próprio Ocidente.

5 Mignolo, 1981: 394. González Echevarría, 1984: 158-159.
} 
vituperio". ${ }^{6} \mathrm{O}$ critério de verossimilhança era definido pela capacidade persuasiva de edificar moralmente o leitor, de produzir nele o pathos, a reação emotiva. É assim que, em sua análise da crônica do franciscano Pedro de Aguado sobre os índios de Nova Granada, Borja Gómez mostra que o uso de contrastes era uma estratégia discursiva fundamental. A comparatio permitiria explicitar ao leitor os vícios e virtudes dos personagens, a tal ponto que o referido frei Aguado organizou sua obra de forma que, nos livros em que o conquistador era descrito como virtuoso, os índios apareciam como tiranos, e quando os espanhóis tiranizavam, os comportamentos dos nativos não se afiguravam assim tão maus. ${ }^{7}$

A compreensão de que havia, entre os índios amazônicos, hordas de bárbaros sem fé, sem lei e sem rei, era inseparável da suposição de que, nessas mesmas regiões, havia índios mais propensos a aceitar a vida em polícia e a doutrina cristã, grupos que os espanhóis rotulavam como "amigos", em oposição aos anteriores. As profundas divisões, oposições, solidariedades e diversidade de costumes que existiam entre grupos artificialmente classificados, pelos colonizadores, como "de paz" ou "de guerra", indicam o arbitrário do dispositivo colonial de construção dessa taxonomia dicotômica. ${ }^{8}$ Assim, por exemplo, com a chamada "guerra chichimeca", empreendida pelos espanhóis na fronteira da Nova Espanha ainda na segunda metade do século XVI, o nome "chichimeca", havido por descendente da nobreza dos índios do México pré-colonial, converteu-se em sinônimo de "indio de corso". ${ }^{9}$ Como observa Giudicelli, a trajetória do etnônimo Chichimeca é análoga aos dos nomes atribuídos a grupos não conquistados no Chile ou no Paraguai: do ponto de vista da colonização, constituíam "le paradigme de la barbarie, la catégorie générique servant à désigner l'espace symbolique à conquérir, la barbarie à civiliser". ${ }^{10}$ Do mesmo modo, um parecer escrito em princípios da década de

6 Valadés, 1989 [1579]: 49 e 166.

7 Borja Gómez, 2002: 108; 2005: 34, 36, 44 e 48.

8 Giudicelli, 2001: 42.

9 A expansão mineira em direção ao norte, deflagrada no século seguinte, vendo-se precipitada em uma urgente necessidade de mão de obra, encontrou-se com grupos Pame, Guamare, Guachichil, Zacateco e outros, que não possuíam quaisquer características de nômades ou belicosos, mas ainda assim caíram sob a definição de "chichimeca", o que justificava sua captura para o serviço pessoal (Giudicelli, 2001: 42).

10 Giudicelli, 2001: 43. A oposição entre "mansos" e "salvajes" reaparece em várias regiões e seria impossível enumerar aqui os trabalhos que dão conta delas. Dentre os textos que mais inspiraram o presente estudo, ver: Vitar, 1995: 108-109. Gutiérrez, 1991: 153 et passim. Para o caso amazônico: Ugarte, 2009: 444-465 et passim. Sobre os esquemas com que os portugueses classificavam os índios segundo a dicotomia Tupi-Tapuia, Monteiro, 2001: 59 e ss. 
1570 pelo licenciado Juan Polo de Ondegardo, a respeito da guerra que se devia dar aos Chiriguanos do Peru, sublinhava que sob esse etnônimo se podia enquadrar vários povos indígenas sem prejuízo da exatidão: "por este nombre llaman a todos los yn.os que biven de la guerra, que son muchas naciones [...]. Mejor se entiende esto en el Río de la Plata [...] porque ay chiriguanaes de diferentes nombres, unos guatataes, aguazes, guaycuros y topis y carives". ${ }^{11}$

Outro aspecto para o qual os relatos de colonos e missionários continuamente chamavam a atenção era a presença ou ausência de autoridade política entre os nativos. Não parece de todo inverossímil que a ambiguidade dessas descrições, que hesitavam em reconhecer a autoridade dos caciques sobre os índios comuns, conformassem uma operação discursiva que acabava por legitimar a própria intervenção das instituições coloniais sobre a população considerada. É possível que procurassem criar ou reproduzir uma imagem de "índios bárbaros" em quem, por definição, as relações de obediência eram muito tênues ou mesmo inexistentes. ${ }^{12}$ Por outro lado, o reconhecimento de que os chefes locais eram obedecidos por seus conterrâneos visava atestar às autoridades de Madri que determinado grupo já contava com os alicerces para a sua incorporação nas instituições coloniais. Colonos e jesuítas eram ambíguos a esse respeito, e não era incomum que um mesmo grupo fosse descrito como "descabeçado" ou obediente, segundo as circunstâncias para as quais o informe havia sido escrito. Se havia jesuítas que, mesmo contra as evidências, afirmavam que determinado grupo desconhecia a sujeição a qualquer autori-

11 Informe do licenciado Juan Polo de Ondegardo [c. 1571], Archivo General de Indias (AGI), Patronato, leg. 235, ramo 1, doc. 3, f. 2. Para mais detalhes a respeito desse informe, ver: Pino Díaz, 1995: 77.

12 Giudicelli, 2009: 30-35. Neste texto, entendo as noções de imagem e representação como intercambiáveis e adoto, por critérios de estilo, a primeira e não a segunda. Consoante ao que sugere Bronislaw Baczko, parto do princípio de que os imaginários sociais podem ser controlados ou manipulados: "Toute société doit inventer et imaginer la légitimité qu'elle accorde au pouvoir", sendo certo que "les élites politiques se rendent rapidement compte du fait que le dispositif symbolique constitue un instrument efficace pour influencer et orienter la sensibilité collective, pour impressionner les foules sinon pour les manipuler" (Baczko, 1984: 33 e 53). Em direção semelhante, Roger Chartier define representações como esquemas de classificação que organizam a apreensão do mundo social, isto é, como categorias que filtram e hierarquizam a percepção do real. Produzidas por indivíduos e grupos, que as podem manipular segundo seus interesses, aspiram à universalidade, mas são sempre determinadas pelas disposições dos que as forjam. Como dispositivos de poder e de dominação, longe de ser discursos neutros, intentam produzir estratégias e práticas tendentes a impor uma autoridade, uma deferência e mesmo a legitimar escolhas (Chartier, 1989: 1514; 1990: 17-18). 
dade, era porque - como observa Francisco de Solano ${ }^{13}$ - semelhante estratégia discursiva permitia justificar a limitação das formas aborígenes de poder às balizas aceitáveis à vida em reduções e a substituição de antigos chefes por uma nova geração de nativos educados para ocupar os ofícios municipais. ${ }^{14}$

As franjas da Amazônia localizadas a oriente da Audiência de Quito passaram a ser exploradas mais assiduamente pelos espanhóis nas últimas décadas do século XVI. Entre eles estavam jesuítas e franciscanos, que principiavam suas atividades missionárias entre os nativos. ${ }^{15}$ Até a metade do século XVII, quando as missões religiosas se afirmaram em detrimento das expedições de colonos, foram tecidas diversas imagens dos povos nativos. Nesse período, que concerne ao presente estudo, os índios foram classificados em duas grandes categorias: de um lado, estavam os tidos por amigos, em quem os espanhóis verificavam certos sinais de "polícia"; de outro, os "bárbaros", geralmente retratados como nômades e antropófagos. Uma análise mais acurada dessas imagens mostra que elas se coadunavam com os objetivos

13 Solano, 1990: 352.

14 Quer reconhecessem ou não a autoridade dos chefes nativos sobre suas comunidades, o certo é que sua jurisdição deveria ser reconstruída segundo os parâmetros esperados pelas autoridades coloniais. Solórzano Pereira - distinguido jurista espanhol, que conhecia de perto os problemas americanos-, em sua Política indiana, publicada em Madri, em 1648, retomava uma observação do padre jesuíta José de Acosta, para quem era tanto o império com que os curacas mandavam os índios que lhes eram sujeitos, e tão grande o respeito e o medo que estes lhes tinham, "que no se atreven a replicar ni aun abrir la boca a cuanto les mandan" (Solórzano Pereira, 1996 [1648], t. 1, lib. 2, cap. 27, n. ${ }^{\circ}$ 6: 561). Do mesmo modo, essa autoridade era a chave para conseguir a conversão das populações que, em matéria de fé e assuntos da salvação, pendiam da vontade dos curacas (ibidem, t. 1, lib. 2, cap. 27, n. ${ }^{\circ}$ 37: 569). Entretanto, ainda que a Coroa reconhecesse os caciques como senhores naturais e chegasse a proibir que se interferisse na sucessão por direito de sangue (ibidem, t. 1, lib. 2, cap. 27, n. ${ }^{\circ} 11$ : 562), concebia, também, que as mais das vezes eles agiam como verdadeiros tiranos, ao dispor das pessoas e bens segundo a sua vontade e sem atenção à justiça. O que era tanto pior quando excediam o papel que se lhes esperava na administração dos índios comuns, "haciéndoles en las cobranzas de los tributos y en repartimientos de las minas y en todo lo demás que pueden infinitas estafas y extorsiones y violencias" (ibidem, t. 1, lib. 2, cap. 27, n. ${ }^{\circ}$ 6: 561). Daí porque o ilustre jurista conclui com a lembrança de uma fórmula conhecida, segundo a qual "ningunos son peores para mandar que aquellos a quien la naturaleza crió para obedecer y servir" (ibidem, t. 1, lib. 2, cap. 27, n. ${ }^{\circ}$ 8: 562). Ver também: Baciero, 2006: 319. Desse modo, as "descrições" sobre a autoridade de que dispunham os chefes nativos (ou sobre a falta dela) devem ser tomadas com cuidado, sem perder de vista o modo como missionários e colonos pretendiam transformar as relações de mando e obediência e integrá-las nas instituições coloniais.

15 Dentre as obras que abordam esse processo, ver: Jouanen, 1941; 1943. Rumazo González, 1946. Oberem, 1980. Renard-Casevitz, Saignes e Taylor, 1988. Newson, 1995. Taylor, 1999. Espinoza Soriano, 2007. Gómez González, 2014. 
Figura i. Piemonte andino e Amazônia ocidental, NA JURisdição DA AUDIÊNCIA DE QUITO, EM MEADOS DO SÉCULO XVII

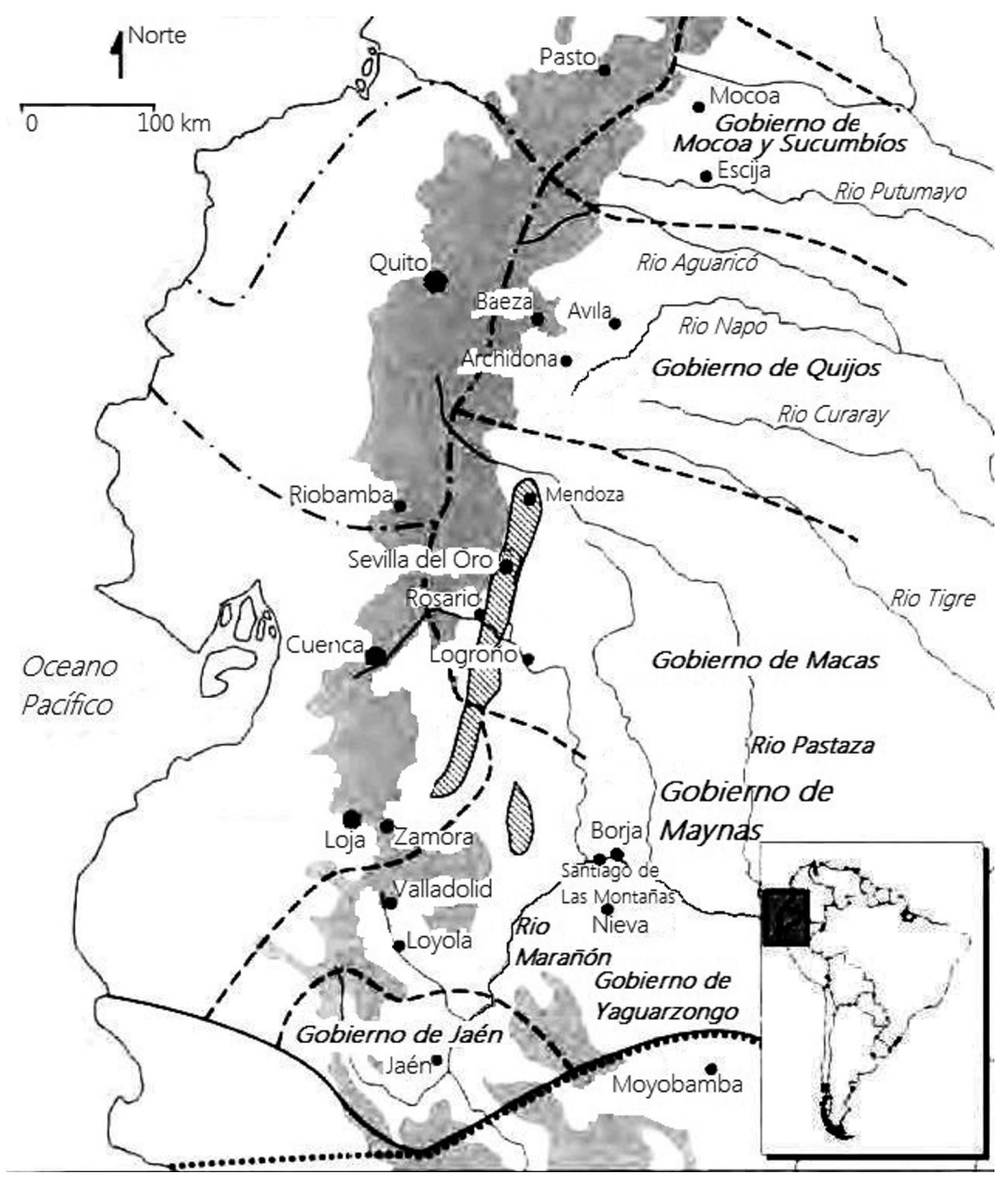

Legenda: O tracejado indica a delimitação das governações; o pontilhado, a da Audiência de Quito; e a linha contínua, a do bispado de Quito.

Fonte: Adaptação de mapa publicado por Taylor, 1999: 212.

específicos de colonos e missionários, vale dizer, a captura de mão de obra para o serviço pessoal e o estabelecimento de reduções. As descrições contidas nesses informes eram antes prescrições, imagens projetadas para um futuro próximo em que as referidas populações seriam admitidas, por meio da força ou da persuasão, nas instituições coloniais. 
A dicotomia estabelecida entre índios amigos e índios bárbaros expressava, ademais, o que os contemporâneos entendiam pela noção de "polícia". Nos séculos XVI e XVII, a palavra policía, em espanhol, com suas raízes grega (politeia) e latina (politia), era um termo complexo, que implicava, na acepção de Aristóteles, a subordinação, por meio das leis, dos interesses individuais aos da comunidade: policía, nesse sentido, dizia respeito à ordem, à paz e à prosperidade que um bom governo devia proporcionar. Mais tarde, Cícero utilizou politia como sinônimo de urbanitas, para referir-se às boas maneiras e ao refinamento, em oposição à rusticitas. Para os espanhóis da época aqui estudada, a policía, em todos os seus aspectos, era entendida como um atributo dos moradores das cidades, do qual estavam desprovidos aqueles partidários da vida ambulante ou seminômade, do vivir alárabe, como se dizia dos mouros, gitanos e ameríndios. ${ }^{16}$

É certo que o adjetivo "civilizado" não era comum em língua espanhola até princípios do século XVIII, e mesmo o Diccionario de Autoridades (Real Academia Española), publicado entre 1726 e 1739, dava à palavra civil um sentido negativo: "En su recto significado vale Sociable, urbáno, cortés, politico y de prendas proprias de Ciudadáno; pero en este sentido no tiene uso: y solamente se dice del que es desestimable, mezquino, ruin, y de baxa condicion y procedéres". ${ }^{17}$ A noção que interessa aqui, e a que era mais difundida no período em questão, a de polícia, combinava pelo menos dois sentidos, ambos inseparáveis da atividade urbana: um público, vinculado à cidadania em um governo organizado, e outro relacionado à conduta pessoal e à vida privada. Já a definição que Sebastián de Covarrubias fez constar no Tesoro de la lengua castellana, de 1611, indicava essa complexidade: "Policía, término ciudadano y cortesano. Consejo de policía, el que govierna las cosas menudas de la ciudad, y el adorno della y limpieza". ${ }^{18}$ Também Lechner pôde distinguir, entre os textos de época, as mesmas variações de sentido. De um lado, remetia à "arte de governar", ou seja, às relações de natureza política, "de orden y concierto en el gobierno, forma de convivencia ordenada y basada en leyes". ${ }^{19}$ Em reflexão sobre se os índios sabiam governar bem as suas casas, desenvolvida em sua Apologética Historia Sumaria, frei Bartolomé de Las

16 Kagan y Marías, 1998: 59-60. Para as confrontações dos índios com os mouros: Gerbi, 1978: 332.

17 Real Academia Española, 1729, vol. 2: 364.

18 Covarrubias Orozco, 1611: 591v.

19 Lechner, 1981: 406. Nas palavras do dicionário da Real Academia Española, 1737, vol. 5: 311: "La buena orden que se observa y guarda en las Ciudades y Repúblicas, cumpliendo las leyes o ordenanzas, establecidas para su mejor gobierno". 
Casas parecia referir-se à ideia de república ordenada ao afirmar que "la verdadera y propia policía [...] consiste en la justicia, conviene a saber, cuando cada vecino o ciudadano y miembro de aquella república es contento con lo suyo y tiene la disposición que conviene a su estado y a su oficio y en él obra según debe". ${ }^{20}$ Por outro lado, era comum o uso de polícia com o sentido de "refinamento de modos", compostura, asseio, polidez, delicadeza e outras acepções semelhantes, que remetiam à conduta apropriada no trato cortesão. ${ }^{21}$ O padre José de Acosta, por exemplo, manejava e alternava ambos os sentidos, como quando se refere às flores e mais adereços com que os Cholutecas adornavam seus templos e arcos, "con toda la policía posible"; 22 e ao comentar a forma de governo dos Astecas, escreve que "en la hacienda también tenía[n] su policía y buena administración, teniendo por todo el reino repartidos sus oficiales y contadores y tesoreros, que cobraban el tributo y rentas reales". ${ }^{23}$ Entretanto, a grande preocupação de missionários e juristas, segundo alude Coello de la Rosa, era a de conformar uma nova ordem política edificada segundo os preceitos da polícia e da doutrina cristãs, ambicioso projeto em que as reduções aspiravam a ser a pedra angular, pois nelas os índios viveriam em cidades e adotariam as normas da sociedade civil e a religião dos adventícios. ${ }^{24}$

Que a região amazônica era compreendida como uma região de fronteira, onde viviam grupos que até então não puderam ser reduzidos (e que por um bom tempo continuaram virtualmente "independentes"), atestavam-no as estratégias utilizadas por missionários e colonos para aproximar-se daquelas populações. Os próprios jesuítas não descartavam o recurso às entradas armadas dirigidas a atrair, pela força, índios "infiéis" às reduções ou destinadas a reprimir grupos recalcitrantes. ${ }^{25}$ Aqui, como em outras zonas fronteiriças do império, as missões de religiosos e as expedições militares de colonos, como lembra Hausberger, mantiveram em toda a época colonial uma relação antes de tudo simbiótica, e era raro ver umas desprovidas da companhia das outras. ${ }^{26}$

${ }^{20}$ Las Casas, 1967 [1559], t. 1, cap. 45: 241.

${ }^{21}$ Real Academia Española, 1737, vol. 5: 312, recolhe "cortesía”, "aseo", "limpieza", "curiosidad" e outros.

22 Acosta, 2008 [1590], lib. 5, cap. 30: 198.

23 Ibidem, lib. 6, cap. 25: 225.

24 Coello de la Rosa, 2000: 93. Sobre o conceito de "policía cristiana", escrevem Kagan e Marías (1998: 60) que ele "provenía principalmente de la Ciudad de Dios de San Agustín, la noción tomista de la ciudad como instrumento de evangelización, y las ideas de [Francesc] Eiximenis sobre la 'cosa pública cristiana', [que] vinculaban la ciudad al cristianismo".

25 Cipolletti, 1999: 224.

26 Hausberger, 1993: 34 e 40. 
É assim que, nas missões jesuíticas de Casanare, Meta e Orinoco, até vinte soldados fincavam residência em cada redução, de onde escoltavam os padres em suas jornadas. ${ }^{27}$

Em atenção à diversidade de situações em que deviam atuar os missionários, o inaciano Acosta chegou a propor três métodos de evangelização para o que distinguia entre três tipos de bárbaros. ${ }^{28}$ Povos "sin ley, sin rey, sin pactos, sin magistrados ni república, que mudan la habitación, o si la tienen fija, más se asemeja a cuevas de fieras", somente podiam ser convertidos com o auxílio da força, vale dizer, por missionários que trabalhassem em companhia de soldados que protegiam as suas vidas. Era necessário forçá-los a juntar-se e a sair da selva, antes de compeli-los a entrar no reino dos céus com outros métodos. Nações como as dos Incas e Astecas, que possuíam cidades, formas de governo, magistrados e leis, podiam ser administradas por um governador cristão, que cuidaria de zelar pelo trabalho dos evangelizadores e de reforçar continuamente a adesão ao cristianismo. Por fim, somente entre as nações civilizadas da Ásia, como a China e o Japão, podiam os religiosos aplicar o mesmo método utilizado pelos apóstolos entre os gregos e os romanos, ou seja, o ensino pacífico e racional que não envolvia mudança de governo. ${ }^{29}$

Se, para os missionários, a busca de apoio entre as autoridades coloniais para as reduções que esperavam fundar na fronteira amazônica orientava as imagens que construíam a respeito dos índios, do ponto de vista dos colonos, o mais urgente era a obtenção de licenças para a realização de expedições e de concessões de encomiendas entre os grupos contatados. Estudos recentes têm mostrado que as imagens fantásticas a respeito dos índios e da paisagem das terras baixas da América do Sul, que adornavam os memoriais que os colonos submetiam ao Conselho das Índias (Consejo de Indias), longe de expressar uma predisposição pelo maravilhoso, decorrente de um suposto "contágio" pela "febre" do El Dorado, ${ }^{30}$ respondiam, em realidade, a interesses mais concretos. Essas imagens eram mobilizadas e manipuladas, de forma

\footnotetext{
27 Rey Fajardo, 1995: 67-68.

28 Acosta, 1952 [1588], "Proemio": 46-48 (para a citação a seguir: 47-48), e lib. 2, cap. 8: 169-173.

29 A distinção permitiu a elaboração de métodos específicos para as missões volantes, entre índios doutrinados por curas, e as "misiones a infieles", auxiliadas por escoltas militares. Mais detalhes em: Maldavsky, 2012: 75 e 87.

30 Ramos Pérez relevou a "predisposición mítica" dos colonos e argumentou que as notícias se espalhavam como que por contágio (Ramos Pérez, 1973: 323 e 376-377). O estudo de Juan Gil, por sua vez, parece mais atento às utilizações pragmáticas do fantástico, como quando analisa os memoriais que Martín de la Riva Herrera remeteu à Corte, na década de
} 
oportunista - vale dizer, atenta ao que as autoridades de Madri esperavam ouvir-, por aventureiros e buscadores de fortuna de diversas origens sociais, mas que se encontravam em regiões marginais e desprovidos de recursos. Daí porque, na dura negociação com os funcionários reais, as imagens do $E l D o$ rado e de índios "caribes" ou "polidos", hostis ou amigos, conforme as circunstâncias, podiam compor um discurso suficientemente persuasivo para obter a adesão da Coroa se não a pedidos de governações e títulos, ao menos a súplicas mais urgentes de licenças para a realização de expedições e a concessão de encomiendas. ${ }^{31}$

E a esse respeito, a região da Amazônia ocidental constitui um espaço privilegiado de pesquisa, especialmente entre os séculos XVI e XVII, época em que os colonos empobrecidos das cidades circunvizinhas se empenharam em apresentar à Coroa seus "méritos y servicios", com o fim de inclinar o favor real às suas súplicas de encomiendas e de outras mercês. Memoriais em que os colonos ressaltavam sua participação em entradas destinadas a atrair ou a reprimir grupos independentes, que conferiam, às encomiendas, um status de prêmio e direito de conquista. Na região de Quijos, por exemplo, onde os encomenderos contavam, pelo ano de 1608, com uma média de 40 a 50 tributários, as costumeiras alegações de pobreza e de que os braços já concedidos haviam desertado eram recorrentes em seus requerimentos. Também era comum afirmar que a comunidade havia sofrido ataques de "índios bárbaros" ou que existiam ricos minerais naquelas proximidades. ${ }^{32}$

A primeira parte deste texto analisa a taxonomia dicotômica com que colonos e missionários classificavam os índios amazônicos. Aparentemente, havia certos critérios que permitiam identificar determinado grupo como amigo, a exemplo da vida sedentária, dos cultivos e do uso de roupas, ou como "bárbaro", imagem negativa que enfatizava geralmente o que os índios não tinham, como a autoridade dos chefes e os cultivos, além de supor que eram canibais.

$\mathrm{Na}$ segunda parte, procura-se mostrar as ambiguidades daquela divisão, uma vez que os mesmos grupos podiam ser retratados como amigos ou "bárbaros", segundo os objetivos e o destinatário dos que redigiam os informes.

1650, em que se dizia governador de Chachapoyas, Moyobamba, "y todas las demás provincias de indios infieles que hay de los tabalosos a las costas del Brasil" (Gil, 1989: 264 e ss.).

31 Entre os estudos mais destacados que, nas últimas décadas, têm enfatizado as dinâmicas sociais por trás dos mitos de El Dorado e Paititi, e de outras imagens construídas a respeito dos índios e da paisagem das terras baixas, ver: Lorandi, 1997. Scott, 2009. Livi Bacci, 2012. Cardoso, 2012. Gómez González, 2014.

32 Sobre os encomenderos da região de Quijos, no século XVII, ver: Oberem, 1980: 90-106. 
Assim, a alegada propensão de certos grupos por realizar incursões e comer carne humana podia servir como justificativa em requerimentos ao poder central para a realização de expedições e a conquista daquelas populações. Ou ainda, não reconhecer a autoridade dos chefes de certos grupos podia servir aos missionários para justificar sua presença e a tutela que exerciam sobre índios que, segundo o seu entendimento, não podiam governar a si mesmos.

Finalmente, o texto passa ao exame do mito do El Dorado, imagem recorrente em âmbito amazônico, por meio da qual colonos e missionários referiam-se às riquezas minerais ocultas nas selvas. Um exame mais detalhado desses relatos mostra que as notícias de minas serviam, em realidade, para chamar a atenção a respeito da possibilidade de recrutar determinadas populações para o serviço pessoal. Expedições que perseguiam quimeras de ouro não raro retornavam com um bom número de "peças de serviço", que compunham as encomiendas dos colonos das cidades circunvizinhas.

\section{ÍNDIOS AMIGOS E ÍNDIOS "BÁRBAROS"}

As primeiras referências sobre os índios Maynas davam conta de sua idiossincrasia pacífica e laboriosa, como se extrai da carta ânua da Província do Peru da Companhia de Jesus, de 1595. Naquela oportunidade, os jesuítas fizeram constar as notícias divulgadas por um cacique, que havia estado em Huamanga, e por um espanhol, natural de Múrcia, que havia recorrido aquelas paragens: "Los habitantes, según pudieron entender por su vestido y apariencia exterior los que navegaron aquellos ríos, parecen muy tratables y de índole apacible". ${ }^{33}$

Os primeiros contatos com os índios Maynas, contudo, puseram em dúvida aquela imagem de índios mansos e amigos. Em 1615, uma incursão havia custado a vida de alguns moradores de Santiago de las Montañas e de Santa María de Nieva, cidades fronteiriças da jurisdição de Quito. A hostilidade era uma resposta dos nativos às contínuas entradas espanholas em suas terras e à captura de "peças" para o serviço pessoal. Nova entrada desse tipo partiu de Yaguarzongo, em fevereiro de 1616, sob o comando do capitão Luis de Armas Vetancur. A armadilha, composta de 20 espanhóis e 20 índios, desceu o rio Marañón para além da queda d'água conhecida como Pongo de Manseriche

33 Jouanen, 1941: 334. 
e atacou os Maynas. Uma vez trazidos a Santiago, os cativos principiaram algumas conversações de paz, comércio e amizade. ${ }^{34}$

Logo se restabeleceu a reputação dos Maynas e de suas terras, e tanto era assim que, no título do governador escolhido pelo vice-rei para o vale do rio Marañón constava a imagem geralmente aceita de que a paisagem era plana e dilatada; abundante em fruta, carne, pescado e outras coisas necessárias à vida humana; o clima temperado; os índios Maynas somavam umas oito mil almas; "gente dócil, mansa y agradable", "vestidos de ropa de pincel muy linda"; dispostos a fundar uma cidade no Sítio de los Naranjos, junto ao Pongo. Diego Vaca de Vega, sucessor no governo de Yaguarzongo, caudilho experiente que já combatera corsários ingleses e havia sido corregedor de Chachapoyas e Moyobamba, foi o escolhido pelo vice-rei para assentar uma cidade de espanhóis naquela fronteira. As capitulações garantiam que índios Maynas, Cocamas, Jívaros e outros podiam ser distribuídos em encomiendas aos povoadores, "según sus méritos y servicios". ${ }^{35}$

Assim, mais de um informe contribuía para tecer uma imagem positiva dos índios Maynas como indios amigos, em contraposição a outros grupos amazônicos. Cristóbal de Saavedra, mestre de campo da expedição de Vaca de Vega que, em 1619, fundou a cidade de San Francisco de Borja, no vale do rio Marañón, observou a respeito dos Maynas que "es esta gente dócil y fiel". ${ }^{36}$ "Es gente limpia y muy ingeniosa", o que ficava manifesto nas roupas que fabricavam e vestiam, as quais "labran de pincel, de diferentes colores, con mucha curiosidad". A autoridade dos chefes era firmemente difundida entre aqueles nativos: "respetan y obedecen con mucha puntualidad a sus caciques"; não lhes davam "tributos particulares, mas de tan somente hacerles sus chácaras y casas en comun", além de atendê-los nas tropas que coordenavam para pescar e caçar. ${ }^{37} \mathrm{O}$ quadro se completava com a ausência de

\footnotetext{
34 Anda Aguirre, 1995: 26-27. Gil, 1989: 246-247.

35 "Título de gobernador" [a Diego Vaca de Vega, Príncipe de Esquilache, Callao, 17 de setembro de 1618], Revista de archivos y bibliotecas nacionales, 2/3 (Lima, 1899): 181-182.

36 Relación de la entrada que hizo el gov.r Don Diego Baca de Vega, al descubrimiento y pacificación de las provincais de los indios Maynas, Cocamas, y Gibaros, por Cristóbal de Saavedra [ant. a 24 de abril de 1620], AGI, Lima, leg. 39, ff. 258-259.

37 Suas casas consistiam em galpões dispersos em que viviam até três parentelas. A poliginia estava generalizada, e cada homem tinha uma média de duas a três esposas. A divisão sexual do trabalho consistia em que as mulheres se ocupavam da horticultura, tecelagem e olaria; e os homens da caça, da pesca e da guerra. Cultivavam sapota, banana, papaia, pupunha (chonta), abacaxi, milho, feijão, amendoim, calabaça, mandioca, batata doce e outros tubérculos. Bebiam chicha de mandioca, de milho, de chonta ou de llantén. Fabricavam uma bela cerâmica colorida. As mantas e as esteiras que produziam serviam de moeda. Dispunham,
} 
idolatrias, sacrifícios e outros traços próprios de índios "bárbaros": "No tienen ídolos ni adoraciones, ni saben si hay Dios o no, y sólo tienen una simple gentilidad con abusiones de sueños y algunos cantos de pájaros". 38

Em geral, índios que fabricavam vestimentas eram vistos como menos bárbaros do que seus vizinhos que andavam desnudos. Assim, por exemplo, o mesmo Cristóbal de Saavedra, ao referir-se aos Cocamas, supunha constituírem uma província "muy poblada de gente en más número de 20.000 indios de manta y camiseta, muy dócil, de buena disposición y voluntad". ${ }^{39}$ Havia, portanto, uma relação direta entre roupas e polícia, como se depreende do que diz o lusitano Maurício de Heriarte, que viajou do Pará a Quito com Pedro Teixeira, entre 1637 e 1639, ao fornecer uma imagem bastante favorável a respeito dos Cambebas. ${ }^{40} \mathrm{O}$ fato de andarem vestidos parecia a confirmação material de que eram inclinados ao trabalho regular: "He gente cuidadosa, trabalhadora e forte. Costumão andar vestidos com camisas e calçõens, a seu uso: as molheres com mantas e camisoens, em que mostrão ser mais honestas que os mais Indios do rio, que vivem nûs, e com desonestidade". As mulheres eram quem fiavam e teciam: "Fazem as roupas que vestem, e muitas que levão por trato a outras provincias". ${ }^{41}$ Essa boa índole ainda atenuava o fato de serem idólatras, pois pelo menos não eram antropófagos como outros grupos ribeirinhos: "São todos idolatras e tem casa de Idolos, a que fazem sacrificio dos que cautivão na guerra. Untão os idolos com o sangue, e as cabeças dos sacrificados teem em casas apartadas, que servem só deste thesouro por tropheo de sua religião". Os corpos, finalmente, eram enterrados, "por quanto estes Indios não comem carne humana, nem outro genero de carne". ${ }_{42}$

Um caso exemplar da manipulação das imagens dos índios amazônicos pelos europeus é o dos Omaguas que viviam, no século XVI, no vale do rio Napo. ${ }^{43}$ Por um bom tempo, eles foram tidos por protótipos dos "índios ami-

já àquela época, de não poucos utensílios europeus (Relación de la entrada, por Cristóbal de Saavedra [ant. a 24 de abril de 1620], AGI, Lima, leg. 39, ff. 258-259).

38 Idem. Renard-Casevitz, Saignes e Taylor, 1988: 100-101.

39 Relación de la entrada, por Cristóbal de Saavedra [ant. a 24 de abril de 1620], AGI, Lima, leg. 39, f. 258. Ênfase acrescentada.

40 Sobre a presença dos portugueses no vale do rio Amazonas, durante a União Ibérica, e os vários projetos que formularam para a navegação daquele rio, ver: Cardoso, 2012: 70, 210 et passim.

41 Heriarte, 2000 [1662]: 232.

42 Idem.

43 Antes que os espanhóis penetrassem nas regiões a leste da cordilheira, alguns grupos se haviam separado do núcleo principal dos Omaguas, de fala Tupi, que habitavam certo passo do vale do rio Amazonas chamado de "Gran Omagua". Esses grupos subiram o rio Napo 
gos" que poderiam existir na Amazônia. Em fins do século XVI, observadores adventícios afirmavam a excelência dos costumes dos Omaguas do Napo, quando comparados aos dos demais nativos. ${ }^{44}$ Toribio de Ortiguera, alcaide da cidade de Quito, em sua crônica terminada em 1586, dedicou algumas páginas à expedição de Gonzalo Pizarro, continuada por Francisco de Orellana pelos rios Napo e Amazonas, sucedida há mais de quatro décadas, e assinalou que: "Es la gente de este río [Napo] pulida, bien agestada y dispuesta; vestidos de manta y camiseta de pincel, pintada de diferentes suertes y colores, y las mujeres con ropas de las mismas pinturas". Não deixou de aludir, ainda, aos sinais de existência de metal precioso: "entre ellos había algunos que traían patenas de oro en los pechos, y las mujeres orejeras dello en sus orejas, y otras piezas en las narices y gargantas". 45

Foram os jesuítas os primeiros missionários que atuaram entre os Omaguas do rio Napo. Entre 1606 e 1607, trabalharam entre eles os padres Rafael Ferrer e Ferdinando Arnulfini. Ao que parece, abandonaram momentaneamente seu projeto, ao perceber que os espanhóis de Quijos avançavam sobre as missões para incorporar índios cristãos às suas encomiendas e obrigá-los a lavrar ouro. ${ }^{46}$ Entre 1621 e 1622, os Omaguas receberam a doutrina cristã dos inacianos padres Simón de Rojas e Umberto Coronado, e do irmão Pedro Limón. Deve-se ao informe deste último, incorporado às notícias do padre Maroni, a alusão de que as cem famílias reduzidas na povoação de San Juan de los Omaguas vestiam "ropa de algodon, los indios camisetas, las indias unas mantillas de la cintura para bajo" ${ }^{47}$ Era gente "cudiciosa en el trabajo e inclinada notablemente a guerrear, y cuando no tienen con quien, arman entre sí grandes pendencias, causadas de la embriaguez", embora isso não sucedesse com frequência, "por ser en esta parte algo sobrios". 48

Do mesmo modo que em relação aos Maynas, as descrições sobre os Omaguas contrastavam a civilidade desses índios à barbárie reinante entre outras nações. Segundo informa o autor de uma "Relación del descubrimiento del Río de las Amazonas", de 1639, a maior parte dos índios amazônicos "son idolatras, que adoran dioses falsos", embora desprovidos de templos,

e se estabeleceram nas margens do seu curso médio e superior, e confluência com o rio Aguaricó (Oberem, 1981: 358. Renard-Casevitz, Saignes e Taylor, 1988: 134).

44 Chaumeil e Fraysse-Chaumeil, 1981: 65.

45 Ortiguera, 1981 [1586]: 61.

46 "Relación apologética así del antiguo como el nuevo descubrimiento del río de las Amazonas" [por Rodrigo de Barnuevo, S.J., Madri, 1643], Informes de jesuitas en el Amazonas, 1986: 116-117. Jouanen, 1941: 102-103.

47 Maroni, 1988 [1738]: 216.

48 Idem. 
cerimônias ou sacerdotes para reverenciá-los. "Casi todas estas naciones andan desnudas"; contudo, os Omaguas se destacavam por suas produções têxteis: "visten camisetas y mantas de algodón, pintadas con pinzel de diversos colores, azul, amarillo, naranjado, verde y colorado, de donde se colige que ai maderas, o iervas en la orilla del río en esta provincia de las quales salen los colores dichos". ${ }^{49}$ Outro informe de 1621 já assinalara as potencialidades dos Omaguas para a vida em missões: "son pacíficos, dicen son muchos, conservanse en paz, con nadie hacen guerras, acojen los estraños con benevolencia, no comen carne humana. Visten como los demás ropas de algodón". 50

As descrições dos chamados "índios bárbaros", aqueles grupos independentes que viviam nas fronteiras do império espanhol, reiteravam certos estereótipos transferíveis e adaptáveis, sem que importasse qual etnia concreta fosse "descrita" ${ }^{51}$ Indiferentes a quaisquer observações mais pontuais, numerosos relatos - a exemplo da "Breve noticia" do padre Marbán a respeito dos Mojos (rótulo sob o qual classificava grupos não só diversos, como distantes) - davam conta de que os ameríndios amazônicos eram bárbaros sem polícia, sem governo, sem rei, sem fé, sem lei, vingativos ao extremo e promíscuos em seus matrimônios. ${ }^{52}$

Alguns exemplos permitem ter uma ideia de como se repetiam os mesmos estereótipos. Em Sevilha, por volta de 1677, a Casa de la Contratación recolheu depoimentos de pilotos e outros sujeitos práticos da navegação atlântica; um deles, certo Alonso Bacas, disse a respeito dos índios amazônicos que eram "gentiles e ydolatras que viven sin republica ni orden económico sino

49 Relación del descubrimiento del Río de las Amazonas, oy Río de San Francisco de Quito, y declaración del mapa en donde está pintado, por Alonso de Rojas, S.J. [1639], Archivum Romanum Societatis Iesu, Roma (ARSI), Nuevo Reino y Quito (NR et Q), 15, i, f. 277v. Há transcrição em: Carvajal et al., 1986: 243-244.

50 Relación de las nuevas provincias que por el río Marañón se an descubierto, 1621, ARSI, Brasile, 9, f. 2v. Essa imagem atrelada aos Omaguas, tidos por mais civilizados que os demais nativos, continuou influente durante o século XVIII. O padre Uriarte, que trabalhou na missão de San Joaquín por alguns anos, embora reprovasse o uso de deformar a cabeça das crianças - "ya ban dexando este abuso"-, tinha esse grupo em alta conta: "Por lo demás, son gente mui cariñosa, de su naturaleza carpinteros, y las mugeres, hacen cosas de varro mui pintadas y assi mismo mantas" (Manuel de Uriarte a Maria Francisca [sua irmã], San Joaquín de Omaguas, 29 de agosto de 1761, Lilly Library, Indiana University, Uriarte Mss., folder 1760-1765, f. 2v).

51 Raminelli, 1996: 56.

52 Breve noticia de las misiones de infieles, que tiene la Compañía de Jesús de esta provincia del Perú en las provincias de los Mojos, pelo padre Pedro Marbán, S.J., 1700, AGI, Lima, leg. 407, f. 3. 
en choças que las mudan quando se les antoja"; do que se inferia "no tener poblaciones castillos ni otras fortificaciones ni defensas como también no tener sujeción a nadie ni tener príncipe a quien obedecer ni puertos que guardar". 53

Boa parte dos estereótipos mais recorrentes encontra-se na carta do superior Juan Lorenzo Lucero ao padre vice-provincial, datada de La Laguna, a 3 de junho de 1681, em que descreve de modo genérico os índios da Amazônia ocidental: gente que jamais conheceu príncipe; os filhos sem amor pelos pais, estes indiferentes àqueles; supersticiosos, criam que toda a morte era produto de um feitiço; sacrílegos, recusavam-se a enterrar os mortos na igreja, e preferiam destiná-los ao piso de suas casas ou aos seus estômagos. A carta foi difundida pelo procurador Manuel Rodríguez, que a transcreveu em seu livro El Marañon, y Amazonas. ${ }^{54}$ Do mesmo modo, um prólogo das Cartas edificantes, ao pintar um quadro severo dos índios amazônicos, de modo a justificar a presença dos jesuítas, não ia além da enumeração das conhecidas desqualificações: "No hay nación alguna entre tantas, que no tenga su particular barbaridad; pero se puede afirmar, que el carácter de todas ellas es la estupidez, la perfidia, y la inconstancia". 55

$\mathrm{O}$ argumento da falta de autoridade entre os índios visava sobretudo legitimar a guerra. ${ }^{56} \mathrm{~A}$ falta de chefe político e o comportamento baseado na mútua desconfiança eram alguns dos traços que o padre Lucero atribuía aos Jívaros, em seu informe ao vice-rei datado de 23 de agosto de 1683, em que dava conta da expedição enviada três anos antes, a cargo do governador Mau-

53 Relación de lo que parece por los ynformes que a remitido la Casa de la Contratación, de personas practicas sobre la población que Portugueses yntentan hazer cinquenta leguas adentro del río Marañón, Tomás Miluti [post. a 1677], Real Academia de la Historia, Madri (RAH), Jesuitas, t. 187, doc. 23, f. 224v.

54 Rodríguez, 1990 [1684]: 515-516.

55 "Carta a los RR. PP. Jesuitas" [s.1., s.d.], en Davin, 1757: iv.

56 Ante uma proposta do governador de Tucumán sobre a realização de expedição ao Chaco, um parecer do Conselho das Índias, da lavra do teólogo Tomás Donvidas, datado de outubro de 1679, retomou a expressão compelle eos intrare (Lucas, 14: 23), usada por alguns para justificar conversões forçadas: devido aos "costumbres abominables" dos índios, se podia e devia obrigá-los com as armas a que tivessem "vida política" reduzidos em pueblos. Na mesma consulta, o dictamen de frei Juan de los Ríos chamou a atenção para o fato de que era inútil "el ofrecerles la paz, y buenas alianzas perdonándoles todos los daños, que han causado: porque ni tienen cabeza con quien ajustarlo, ni admiten embajadores, que se las propongan". A entrada se iniciou em 1685 (Informe que dió el P. Tomás Donvidas, S.J., Madri, 8 de outubro de 1679, AGI, Charcas, leg. 283. Parecer del Fray Juan de los Ríos, O.P., Lima, 24 de novembro de 1682, AGI, Charcas, leg. 283. Ambos citados em: Levaggi, 2002: 97-98). 
ricio Vaca de Vega. ${ }^{57} \mathrm{O}$ padre Zarate, escrevendo em 1735, enfatizava a debilidade da autoridade política dos chefes amazônicos como uma dificuldade importante a ser enfrentada pelos jesuítas: "No dejará de facilitarse algo la empresa, si cada parcialidad siquiera tuviese su caudillo, a quien obedecer; pero aun este alivio falta en muchas dellas, porque o no tienen casique, o si le tienen, es tan corta su autoridad, y jurisdicción, que no tienen otro mando, que el de su casa". Somente nas celebrações que culminavam em bebedeiras e em assuntos de guerra "tienen algún sequito por la fama que le asiste de valiente, y grande hechizero". ${ }^{58}$

Não parece excessivo admitir que a ambiguidade presente nas observações sobre a autoridade dos chefes transparecia que o que era descrito variava conforme o sabor das circunstâncias. Alternativamente às mencionadas passagens, existem informes portugueses, como o de Maurício de Heriarte, ouvidor do Pará e participante da expedição de Pedro Teixeira, que sugerem um quadro distinto. Heriarte, que escreve em 1662, chega mesmo a insistir que os chefes possuíam autoridade, como se nota no que diz a respeito dos Carapunas, que viviam nas cercanias do vale do rio Solimões: "Governam-se por Principaes; e cada hum governa sua familia, que toda vive em numa grande casa, e sobre estes todos ha em cada aldeia hum Principal, que a governa". Esses índios praticavam inclusive sacrifícios humanos e antropofagia, rituais que promoviam o prestígio dos xamãs: "Os que fazem este sacrificio sam os feiticeiros, a quem elles teem em veneraçam, e guardão muito respeito". ${ }^{59} \mathrm{Um}$ dos chefes dos Cambebas -índios que, de resto, "governão-se por Principaes nas aldeias"-, tido em melhor conta que os demais, chegava a considerar-se uma divindade, segundo apurou o mesmo ouvidor, que pôde conversar com esse cacique. ${ }^{60}$

57 “Copia de carta escrita al Excmo. Sr. Duque de la Palatta, Virrey de los Reynos del Perú, por el P. Juan Lorenzo Lucero de la Compañía de Jesús” [23 de agosto de 1683], Informes de jesuitas en el Amazonas, 1986: 328. Sobre a referida expedição: Jouanen, 1941: 482.

58 Relación de la misión apostólica, Andres de Zarate, Quito, 30 de outubro de 1735, AGI, Quito, leg. 158, ff. 254-254v. No mesmo sentido escrevia o padre Maroni, 1988 [1738]: 204.

59 Heriarte, 2000 [1662]: 231.

60 “... no meio desta provincia, que he dilatada, há um Principal, ou rei delles, a que todos obedecem com grandissima sujeição; e lhe chamão Tururucari, que quer dizer o seu Deos; e elle por tal se teem. Fallando com elle nos disse que havia nascido no céo, que por se parecer no corpo com aquelles Indios, vivia entre elles, mas que quando the parecia, ao céo subia; e dizendo-lhe que, em quanto estivessemos na sua aldeia se fosse, respondeo que, ainda que ia, era com o espirito, que o corpo deixava na aldeia" (ibidem: 232). 
Uma conexão direta entre a autoridade dos chefes nativos e a facilidade de convertê-los era estabelecida pelos missionários, a exemplo do franciscano frei Laureano de la Cruz, que escrevendo sobre sua experiência entre os Omaguas e descida pelo rio Amazonas, entre os anos de 1650 e 1651, considerava "no muy dificultosa, al parecer, su reducción por ser gente apacible, política y la de más razón y gobierno de todo nuestro gran río, que tenían Caciques principales, a quienes estaban muy obedientes". ${ }^{61}$

A rigor, o horizonte de recepção dos textos influía nas descrições que eles apresentavam. ${ }^{62}$ Os citados informes de jesuítas espanhóis sem dúvida procuravam afirmar a necessidade de recursos e o imprescindível que era a presença da ordem na Amazônia: apresentavam-se como os únicos que podiam tutelar os índios que, desprovidos de "cabeça", não podiam governar a si mesmos. Do lado lusitano, por sua vez, como se nota pelo informe de Heriarte - solicitado pelo governador do Maranhão, Rui Vaz de Siqueira-, a grande preocupação era reivindicar a posse territorial: os portugueses teriam visitado e feito amizade com chefes poderosos, cuja autoridade reconheciam, e essa rede de chefias poderia servir, quando fosse requerido, para conclamar a vassalagem de seus conterrâneos ao rei de Portugal.

Houve na Amazônia quem considerasse que a influência das potências hereges da Europa fosse um fator determinante na oposição de certos índios "caribes" aos missionários espanhóis. ${ }^{63}$ Alarmado com a aliança entre protestantes e índios "infiéis", o jesuíta Juan Martínez Rubio, escrevendo desde Santa Fé em 1693, argumentava que somente com poderosos auxílios de Sua Majestade Católica seria possível "abatir el orgullo y presunción de la herejía, e idolatría, que como hidra de dos cabezas, pretende aponzoñar con su alien-

${ }^{61}$ Cruz, 1879 [1653]: 288. Sobre os primeiros passos dos franciscanos: Rumazo González, 1946: 255-261.

62 Jauss, 1976: 168.

63 O uso da palavra "caribe" para referir-se aos índios que comiam carne humana remonta à época de Colombo, quando o termo estava aparentado aos que designavam entidades "selvagens" que habitavam os ermos europeus. Efetivamente, "canibal" deriva da palavra Arawak caniba, aparente corrupção de cariba, nome que identificava —para os índios Arawak que viviam em Cuba - os nativos das Pequenas Antilhas, chamados Caribes. Lestringant lembra que a semelhança desses termos com a palavra latina canis, que remetia ao mitológico Cynocephalus, indivíduo com cabeça de cachorro, auxiliou sua difusão. Já em 1525, uma ilustração publicada em Estrasburgo mostrava quatro canibais do Brasil, todos com cabeças de canídeos. Em 1604, Louis Guyon de La Nauche publicou uma memória (incluída em Les Diverses Leçons..., liv. 4, cap. 3) em que, baseado em Colombo, Vespúcio e Léry, concluía que o fato de os índios terem os narizes achatados fazia deles Cynocephalus (Lestringant, 1997: 15-21). Ainda sobre as diversas formas de apropriação do "canibal" pelo pensamento europeu, nos séculos XVI e XVII, ver: Agnolin, 2005: 158-160 e 283. 
to pestilencial, las vidas de tantos varones apostólicos, y desterrar de sus confines el estandarte de la Fe". O ódio mortal que as nações caribes tinham dos espanhóis era alimentado pelo "comercio, y trajín, con olandeses, con franceses hereges, con judíos, y con otras naciones perdidas, que andan y residen en la costa, y otros parajes de la Guayana". "Están pacificados con ellos a no admitir nación catholica alguna", prossegue o padre Martínez Rubio, "y asi los dichos indios caribes, agradecidos a los olandeses y otros herejes, profesan enemistad y persiguen mortalmente muy en primer lugar a los padres de la compañía, y a la nación española, pues temen perder su antiguo comercio con la heresia y libertad de conciencia". ${ }^{64}$

Um aspecto continuamente deplorado pelos padres era a centralidade da vingança nas sociedades amazônicas. O padre visitador Zarate fazia finca-pé na dificuldade que opunha à evangelização a inimizade em que viviam aqueles gentios, que se aborreciam a tal ponto uns com a vizinhança dos outros que cultivavam ódios e vinganças. As inimizades eram fomentadas pela diversidade de costumes e idiomas e pelo difundido que estava o recurso aos feitiços. ${ }^{65}$ À proximidade entre as etnias atribuía, por sua vez, o padre Acuña, a intensa inimizade em que se conservavam. Tendo estimado em mais de 150 as nações que viviam na região de Maynas, acresce esse jesuíta que "están tan continuadas estas Naciones, que de los últimos pueblos de las unas, en muchas de ellas se oyen los golpes al labrar los palos en las otras, sin que vecindad tanta les obligue a hacer pazes, conservando perpetuamente continuas guerras". 66

Também em relação à prática da antropofagia os relatos eram ambíguos. Os Omaguas, que os missionários não incluíam entre os antropófagos, aparecem no informe que o lusitano Pedro Teixeira apresentou em Quito ao presidente daquela Audiência, em 1639, como índios "caribes", que mantinham troféus de cabeças dos seus inimigos: "gente mui carnizera y supuesto que todos los del río lo son y se comen unos a otros, estos pasan la mano, porque

${ }^{64}$ Informe do padre Juan Martínez Rubio, S.J., Santa Fe, 19 de abril de 1693, ARSI, NR et Q, 15, i, f. 246.

65 Relación, Andres de Zarate, Quito, 30 de outubro de 1735, AGI, Quito, leg. 158, ff. $252 \mathrm{v}$ e $253 \mathrm{v}-254$.

66 Acuña, 2009 [1641]: 106. Tão importantes eram os inimigos para a organização social dos Encabellados que, como referiu frei Laureano de la Cruz (1879 [1653]: 275), que os visitou em 1647, mesmo a distribuição espacial das casas e assentamentos dependia das relações com os seus êmulos: "Sus poblaciones están partidas en aldeíllas de a cuatro, de a seis y de a ocho casas, y en cada una vive uno o dos Indios con sus mugeres y hijos. Las aldeas estarán apartadas las unas de las otras un cuarto de legua, media legua y una legua". 
no usan otra carne sino la umana". ${ }^{67}$ Maurício de Heriarte, que esteve na comitiva de Pedro Teixeira durante sua viagem de 1637-1639, fez constar em sua "Descrição", composta em 1662, opinião contrária à de seu chefe: tanto era certo que os Omaguas não comiam carne humana, que suas lavouras dependiam justamente do trabalho dos cativos capturados em guerras, a quem mandavam "com grande império, e elles conhecem seu captiveiro, e obedecem com grande humildade". 68

Assim, os observadores chegavam a afirmar opiniões totalmente opostas em relação à prática da antropofagia por determinados grupos. Escrevendo em 1641, o jesuíta Cristóbal de Acuña aludia que a acusação de que os Omaguas eram caribes era uma invenção dos portugueses para justificar seus apresamentos: "es dicho común con muy poco fundamento de los Portugueses que andan metidos en este trato y con esto quieren colorear su injusticia". 69 Não apenas não comiam seus cativos, como os tratavam com afeição, sem sequer se permitir vendê-los: "averigüé con dos Indios de los que habían subido con los mismos Portugueses", escreve o mesmo padre da Companhia, "[y] estos aseguraron que jamás les habían visto comer los esclavos que traían, sino que los que usaban con los más principales y valientes era matarlos en sus fiestas y juntas generales, recelando mayores daños"; os corpos eram lançados ao rio, ao passo que "guardaban por trofeo las cabezas en sus casas". Quanto aos outros cativos, "comen con ellos en un plato, y tratarles de que los vendan es cosa que lo sienten mucho". ${ }^{70}$ É interessante notar que, também em relação aos Tupinambás, que para Pedro Teixeira eram gente aguerrida e caribe, ${ }^{71} \mathrm{o}$ jesuíta Acuña não fez qualquer menção a que praticassem rituais antropofágicos, antes relevou que eram guerreiros "de corazones nobles y ahidalgados", e que o temor que os outros grupos lhes tinham podia ser usado pelos espanhóis para, fiados nessa milícia, conquistar as demais tribos do rio. ${ }^{72}$

Em alguns casos, os jesuítas ajudaram a difundir a imagem de certos grupos como "caribes", como sucedeu com os Gayes, descritos como uma das

${ }^{67}$ Relación del General Pedro Tejeira del Río de las Amazonas para el S.r Presidente, Quito, 2 de janeiro de 1639, Biblioteca da Ajuda, Lisboa (Ajuda), 51-v-41, f. 7.

68 Heriarte, 2000 [1662]: 232.

69 Acuña, 2009 [1641]: 126.

70 Ibidem: 126-127.

71 Relación del General Pedro Tejeira del Río de las Amazonas para el S.r Presidente, Quito, 2 de janeiro de 1639, Ajuda, 51-v-41, f. 6.

72 Acuña, 2009 [1641]: 149. 
mais ferozes e temidas entre todos os que habitavam o vale do rio Pastaza. ${ }^{73}$ Entretanto, alguns jesuítas chegaram a reconhecer que a fama de "caribes" atribuída a certos grupos era errônea. Assim, do costume dos Maynas, Jeberos e Cocamas guardarem as cabeças de seus inimigos advinha a injustificada fama de que eram canibais. ${ }^{74} \mathrm{O}$ missionário padre Juan Magnin dedicou-se ao tema e apurou que, ao contrário do que divulgavam numerosas notícias, eram poucos os grupos que efetivamente praticavam a antropofagia na região de Maynas: "Los Ixinuris, yquitos, yahuas, pyros comen gente. Los Xeberos sólo el corazón comían". E os Roamaynas tinham o costume de avisar ao cativo quando viriam comê-lo, sendo o estilo deste último esperar o fatídico dia. ${ }^{75}$

Assim como não se colocavam em acordo sobre quais grupos eram "caribes", assim também os jesuítas diferiam sobre o conhecimento que cada grupo possuía a respeito do Criador. As opiniões, portanto, variavam consideravelmente. Se o padre Magnin não reconhecia qualquer conhecimento prévio de Deus entre os índios de Maynas, ${ }^{76}$ não podia encontrar apoio para o seu argumento no informe do padre Figueroa, que escrevera no século anterior: "Todas las naciones que hasta aora se han tratado tienen conocimiento de Dios y vocablo con que en cada idioma lo nombran, llamándolo también Nuestro Padre y Nuestro Abuelo"; não bastasse isso, "dicen que crió el cielo, la tierra, hombres y demás cosas, y que criando las comidas para su hijos, que son los hombres, se fue al cielo". ${ }^{77}$ Atestar que os índios reconheciam um Deus criador não impedia o padre Figueroa de reproduzir a perspectiva pós-tridentina de que a religiosidade ameríndia não possuía qualquer institucionalidade, com o que justificava a presença dos missionários: "no le dan culto ninguno, como debieran, en reconocimiento de que es Criador, ni le invocan para cosa, ni para jurar, ni saben qué cosa es juramento". ${ }^{78}$

73 Esses índios, segundo apurou o historiador Jouanen em fontes inacianas, "habían declarado una guerra de exterminio a las tribus de los coronados y oas", de quem devoravam os prisioneiros em seus banquetes, de sorte que os que sobreviviam a seus ataques eram obrigados a emigrar a outras regiões. Semelhante quadro foi pintado pelo padre Lucas de la Cueva ao presidente de Quito, que autorizou o envio de uma expedição militar a cargo do tenente da cidade espanhola de Borja. A entrada teve lugar em 1661, logrou capturar alguns Gayes para intérpretes, mas os inacianos ainda continuaram a ter dificuldades naquela região (Jouanen, 1941: 460).

74 Chantre y Herrera, 1901 [ant. a 1801]: 90.

75 Breve descripción de la Provincia de Quito y de las misiones, Juan Magnin, S.J., 1740, Archivo Histórico Nacional, Madri, Jesuitas, leg. 251, n. ${ }^{\circ}$ 2, doc. 4, f. 24.

76 Ibidem, f. 18.

77 Figueroa, 1904 [1661]: 234.

78 Idem. 
Os missionários pós-tridentinos, além de não reconhecerem que os índios possuíam algum conhecimento de Deus, quando o faziam, e notavam que havia uma palavra na língua indígena para referir-se ao Criador, não a adotavam, antes preferiam manter o termo Dios em espanhol, segundo o princípio da conversão como revelação de Seu nome. Assim também os termos que diziam respeito às instituições e entidades próprias da Igreja romana, como igreja, missa, confessar, padre etc., não foram traduzidos, de modo a evitar um reconhecimento formal à religiosidade indígena e a garantir o monopólio do religioso à Igreja. A rigor, portanto, termos negativos não eram para a língua espanhola, mas para a indígena; daí que os demônios seguissem sendo chamados pelos nomes dos espíritos malignos nativos. ${ }^{79}$

Outro aspecto que importa assinalar é a ambiguidade de certas descrições que apresentam os índios como desprovidos de qualquer tipo de religiosidade. Assim, por exemplo, o inaciano Alonso de Rojas, que escrevia em 1639, sem experiência direta, a partir dos informes dos franciscanos que estiveram no Amazonas, afirmava que "todo este copioso rebaño está sin pastor, vendido a sus vicios y subjecto al demonio, [...] adorado de aquellos miserables que viven en tinieblas y sombra de la muerte, sin que haya quien los alumbre con la luz del santo Evangelio". ${ }^{80}$ Vale a pena examinar mais de perto a passagem em que se refere à religiosidade dos índios: "Todos son idolatras, que adoran dioses falsos, no tienen ritos ni ceremonias para verenciarlos, ni templos de sus ídolos, ni sacerdotes; a los echizeros temen a quienes consultan y estos al demonio, de quien reciben oráculos, y con embuste engañan a los miserables indios". ${ }^{81}$ Algumas questões emergem inevitavelmente da leitura desse texto: como adoravam deuses falsos se não tinham nem sacerdotes, nem cerimônias para eles? Se os xamãs eram uns falsários, de que modo consultavam o demônio? O teor contraditório apenas revela que, embora os jesuítas considerassem que a compreensão dos costumes e crenças nativos era indispensável ao trabalho de evangelização, as imagens dos índios que teciam em seus informes variavam conforme os projetos específicos que os religiosos da Companhia de Jesus formulavam para consolidar sua jurisdição sobre o vale do rio Marañón.

Está visto, além disso, que a caracterização dos índios como "idólatras", pelos jesuítas, ecoava as concepções do padre José de Acosta, que em sua

79 Estenssoro Fuchs, 2003: 87, 93 e 110.

80 Relación del descubrimiento del Río de las Amazonas, oy Río de San Francisco de Quito, y declaración del mapa en donde está pintado, por Alonso de Rojas, S.J. [1639], ARSI, NR et Q, 15, i, f. 277v. Transcrição em: Carvajal et al., 1986: 243.

81 Idem. 
Historia natural y moral de las Indias, de 1590, identificou, entre os povos andinos, adorações dirigidas às coisas da natureza, ao sol, à lua e às estrelas, à terra, aos elementos, aos rios, à primavera, às árvores e às montanhas. Ao que se somava o culto a outra categoria de objetos: aqueles de alguma forma ligados à ação humana, como ídolos e estátuas, é verdade, mas também os mortos e as possessões. ${ }^{82}$ Frei Bartolomé de Las Casas via essas formas de adoração como manifestações de uma religião natural, por atestarem a aspiração humana, ainda que animada pela ignorância e o erro, em direção ao bem e à verdade; e o desejo natural, não necessariamente demoníaco, de conhecer a Deus. ${ }^{83}$ Com vistas a consolidar os ditames tridentinos, José de Acosta e o Terceiro Concílio Limense (1582-1583) romperam com a visão de Las Casas e de outros que acenaram com a possibilidade de acomodação entre doutrina cristã e religiosidade nativa. Assim, as manifestações "religiosas" dos índios não apenas eram produto da ignorância sobre qual era a verdadeira divindade, como também - e principalmente - da emulação do demônio. As idolatrias praticadas pelos nativos resultavam da influência direta do comum inimigo, "que siempre apetece y procura ser tenido y honrado por Dios". ${ }^{84}$

\section{COLONOS, MISSIONÁRIOS E OS ÍNDIOS IMAGINADOS}

A ambiguidade das descrições fornecidas pelos jesuítas decorre, em parte, da finalidade para a qual escreviam. O teor positivo ou negativo com que os índios eram retratados variava segundo o destinatário e os objetivos concretos do autor. $\mathrm{O}$ apelo a imagens positivamente idealizadas da paisagem e dos índios amazônicos pode ser verificado no memorial do procurador Francisco de Fuentes, enviado em 1632, em que solicitava licença para que a Companhia estabelecesse algumas residências ou missões de assento no vasto território da Audiência de Quito. Além disso, pedia mais religiosos para aquela região. ${ }^{85}$

82 Acosta, 2008 [1590], lib. 5, cap. 2: 154, e lib. 5, cap. 5: 157-158.

83 Las Casas entendia que a religião incaica se equiparava, tal como as religiões greco-romanas, a uma praeparatio evangelica; assim, por exemplo, o culto inca do sol, por exaltar as criaturas visíveis de Deus, anunciava a crença em Cristo como Sol da Justiça. Do mesmo modo, o sol inca e as outras divindades relacionadas aos astros foram transformados em uma hierarquia de deuses à maneira da astrologia greco-romana (Las Casas, 1967 [1559], t. 1, cap. 126: 659-662. MacCormack, 1995: 98-99).

84 Acosta, 2008 [1590], lib. 5, cap. 1: 153, e lib. 5, cap. 19: 177. Duviols, 1977: 17-20 e 24-53. MacCormack, 1991: 265-266.

85 Otro memorial del P. Francisco de Fuentes, de la Compañía de Jesús, 1632, AGI, Quito, leg. 88, n. ${ }^{\circ} 53$, f. 7v. 
O texto evidencia que o teor negativo ou positivo das descrições contidas nos memoriais dos jesuítas ajustava-se ao tipo de solicitação que se fazia ao Conselho das Índias. Imagens pragmáticas, e não expressões de um imaginário estático; manipuláveis, e não presas à mera observação. No presente caso, não apenas os índios eram sumamente elogiados, como também a paisagem era descrita como das mais aprazíveis de todo o império. ${ }^{86}$ Agora, quando os inacianos pediam licença para construir mais colégios na jurisdição de Quito, apresentavam os índios amazônicos em geral como "gente pacífica, y trabajadora, y curiosa, de naturales doçiles, y muy dispuestos para recibir nuestra Santa $\mathrm{Fe}$, a causa de no darse a muchos géneros de idolatrías", porque a única que se sabia que tinham era "una casa grande que llaman del Sol, adonde a sus tiempos llegan a ofrecer oro, y plata, y cosas semejantes". Por outro lado, difícil era encontrar índio que andasse desnudo, dado que as véstias de algodão, pintadas com curiosidade, eram amplamente difundidas. ${ }^{87}$

Mais surpreendente é a descrição da paisagem, que em nada lembra o retrato infernal as mais das vezes pintado por missionários da Amazônia: "Las tierras son de temples muy regalados, y sanos, sin frio ni calor demasiado, que moleste", abundantes de comida como milho, carne de caça e pescado, além de muitos outros gêneros; "las entradas y caminos muy fáciles, así por tierra como por los ríos, que se navegan en canoas". ${ }^{88}$ É de notar-se que o inaciano não perdia a oportunidade de acentuar à Coroa os indícios sobre a existência de metal precioso no Marañón: "Ay muchas ricas de oro y plata, como es la Provincia de los Plateros, así llamados, porque labran de oro, y plata, orejeras, y narigueras, que traen pendientes de las orejas, y narizes". 89

Ao justificarem terem abandonado suas missões entre os Omaguas e outros grupos que habitavam o rio Napo, onde estiveram entre 1647 e 1650, os franciscanos retomaram os habituais estereótipos negativos em relação aos índios e à paisagem amazônicos. Como era de esperar-se, aqueles nativos eram desprovidos de qualquer autoridade política: "obligación no la tienen a nadie", escrevia Laureano de la Cruz em relação aos Encabellados, "ni entre ellos hay principales, ni cabeza, ni gobierno y muy poca policía. Tienen a dos

86 Por aquela época, já os jesuítas dispunham de um conhecimento importante a respeito das etnias do vale do rio Marañón, e o padre Fuentes refere pontualmente terem sido contatados os grupos "Xibaros, Xiberos, Quilibitas, Maynas, Plateros, Caparas, Cofanes, Auixiras, Encabellados, Iquitas, Omaguas, Acanecos, Atuaras, Bebacas, Sucumbios, Baduaques, Abalicos, y Micuaras, con las Provincias de las Esmeraldas, Barbacoas, Paez, y Guanacas" (idem).

87 Otro memorial del P. Francisco de Fuentes, de la Compañía de Jesús, 1632, AGI, Quito, leg. 88, n. $^{\circ}$ 53, f. 7v.

88 Idem.

89 Idem. 
mugeres, y algunos a más, y otros hay que no tienen más de una”. Apesar disso, o franciscano reconhecia: "Quieren muchísimo a sus hijos, a cuya causa se crían con mucha libertad y desenvoltura. Conservamonos con esta gente con buena paz y amistad". ${ }^{90}$

Mais severo se mostrou de la Cruz em relação aos Omaguas, convencido de que eram poucos em razão "de matarse unos a otros, de enterrar vivos a los hijos acabados de nacer, y fuera de los que mueren de enfermedades (que ellos no quieren creer sino que los hechiceros los matan)", sem esquecer dos que eram mortos pelos animais da floresta. Viviam, enfim, "tan apartados los unos de los otros, sin policía, razón, ni gobierno, sin principales caziques, ni obediencia a nadie, y que su comercio con los vecinos era matarse, y cautivarse unos a otros". A retirada dos freis não devia surpreender, se a isso se acresce que as ilhas onde habitavam eram estéreis, alagadiças e doentias: "inhabitables a lo menos para Españoles". ${ }^{91}$

Mais tarde, em princípios do século XVIII, os franciscanos que atuavam no rio Putumayo procuraram tecer uma imagem positiva da paisagem natural e humana da Amazônia, com vistas a convencer a Coroa a elevar o subsídio com que financiava aquelas reduções. Em seu memorial de 1711, o procurador frei Manuel de Cisneros referia que, exceto pela inexistência de metal precioso, os terrenos que margeavam o rio Putumayo eram férteis e saudáveis, em tudo adequados a prover os índios do necessário para a vida humana: "los ayres mui saludables y los citios mui sanos, y a orillas y bocas de ríos abundantes de pescado, y las tierras más fértiles que produzen con abundancia lo que siembran para su mantenimiento", o que incluía milho, mandioca, banana e outras frutas e legumes, sem contar os "montes con mucha casería y mui utiles de madera para la fabrica de Yglesia, y casas y para hazer sus piraguas, y canoas". Não parece fortuito que se seguisse daí que os índios daquela região, ao contrário dos da costa, eram considerados mais obedientes e sinceros. ${ }^{92}$

Em alguns casos, pouco importava o perfil cultural dos índios, se a região em que se encontravam era tida por aurífera. Escrevendo pela década de 1650, os franciscanos desconsideraram as imagens de ferocidade, pirataria e oposição à fé cristã, geralmente atribuídas aos Jívaros, para assentar seu argumento sobre a necessidade de reduzi-los, na crença comum de que suas terras escondiam minas de metal precioso. Na opinião de frei Laureano de la Cruz:

\footnotetext{
90 Cruz, 1879 [1653]: 276.

91 Ibidem: 293.

92 Memorial de Fray Manuel de Cisneros, procurador general de las misiones franciscanas, Pasto, 14 de fevereiro de 1711, AGI, Quito, leg. 200, f. 844v.
} 
"es la mayor riqueza de oro que tiene todo el Perú", como a experiência comprovava pelos quintos que renderam à Real Fazenda, devidamente registrados nos livros da comarca de Quito, quando em seu momento os encomenderos utilizavam os Jívaros para trabalhar naqueles minerais. ${ }^{93}$ Em fins do século XVI, uma revolta indígena acelerou o declínio do empreendimento. ${ }^{94}$

Também o capitão Melchor del Mármol, ao propor uma capitulação para a redução dos índios Jívaros, em um projeto que aliava interesses de colonos e religiosos, lembrava que naquela província, segundo antigas tradições, encontravam-se tesouros e opulentas jazidas. ${ }^{95} \mathrm{~A}$ conquista dos Jívaros era apresentada como a solução para pôr fim à pobreza das regiões de Quijos e Macas, governadas por Mármol, e de outras províncias de fronteira. Com o absenteísmo dos encomenderos, que preferiam viver em Quito, seus caixeiros e administradores praticavam toda a sorte de abusos contra os índios, que não perdiam a oportunidade de desertar. Assim, essas regiões permaneciam sem o povoamento adequado previsto nas Reais Cédulas. ${ }^{96}$ Por essa razão, vários religiosos endossaram o projeto, confirmando a crença geral de que aquelas terras eram ricas em ouro, prata e outros gêneros de estimação. ${ }^{97}$

O Conselho das Índias, contudo, parece ter visto com desconfiança o projeto de Mármol. Em resposta ao seu memorial, ordenou que o bispo de Quito tomasse a frente daquele importante negócio. Assinalou ainda o compromisso de descarregar a consciência do monarca com a atração pacífica dos índios à Santa Fé Católica, sem usar de meios violentos. Madri diferia, portanto, dos pareceres que o próprio bispo e a Audiência de Quito haviam enviado, e que recomendavam a conquista pela força das armas. Determinava, por fim, que fosse duramente castigado quem praticasse qualquer violência contra os índios que excedesse a natural defesa. ${ }^{98}$

93 Cruz, 1879 [1653]: 287.

94 Lane, 2002: 139-140.

95 Carta del presidente y oidores de la audiencia de Quito, a S.M., Quito, 20 de maio de 1678, AGI, Quito, leg. 14, ramo 8, n. ${ }^{\circ}$ 34, f. 1.

${ }^{6}$ Memorial de Don Melchor del Mármol sobre estado de las encomiendas en Macas, 1672-1673, AGI, Quito, leg. 14, ramo 8, n. ${ }^{\circ} 34$.

97 La religión de S. Aug.n de la prov.a de Q.to ynforma a VM, Quito, 6 de abril de 1677; El difinitorio de San Fran.co de la Ciu.d de Quito ynforma a V. Mag.d, Quito, 6 de abril de 1677; e La Compañia de Jesus de la Provincia de Quito ynforma a V. Mag.d que será conveniente conseder licencia, Quito, 7 de abril de 1677. Todos em: AGI, Quito, leg. 14, ramo 8, n. 34 .

98 Real Cédula al Obispo de Quito encargándole la reducción de los indios jíbaros y otros, Madri, 17 de setembro de 1680, AGI, Quito, leg. 210, lib. 5, f. 29v. El Fiscal del Consejo de Indias, Madri, 8 de maio de 1680, AGI, Quito, leg. 14, ramo 8, n. ${ }^{\circ}$ 34, f. 1v. 
Também os colonos das cidades contíguas à grande floresta, ao enviarem seus memoriais à Coroa, em que solicitavam capitulação para a conquista daquelas terras, podiam apresentar uma visão positiva dos índios. Em 1630, Gabriel Machacón, tenente general da cidade de San Pedro de Alcalá del Río Dorado, que fazia parte do governo de Quijos, insistia em que os Avijiras e Omaguas, que visitara em várias expedições que realizara na década de 1620 , eram hábeis roceiros e exímios tecedores de roupas "de varios colores y muy finas, y gente belicosa, de grande ingenio". ${ }^{99}$ A terra fértil, limpa com queimadas, permitia semear e colher, por boa parte do ano, milho, amendoim, feijão e outros itens, "de grandísimo sustento que les sirven de pan y vinos". "Las mujeres", segundo o mesmo colono, "gran trabajadoras en sus sementeras y se ocupan de hilar y tejer para sus maridos, y hijos. Gente de buenos rostros, y vestida, onesta de verguença". E mesmo o clima lhe parecia agradável: "Los temples de d.as provincias son buenos, ni frio ni caliente". ${ }^{100}$

Uma descrição da organização política dos índios, surpreendente por evitar o tradicional estereótipo de que eram gente sem lei, nem rei, foi fornecida pelo encomendero Juan de Palácio, em depoimento prestado ao tenente general: "Viven por grandes varrios gobernados por capitanes que el señor de la provincia tiene nombrado. Los malos son castigados de los capitanes con tanto vigor, que tienen açote y también al que lo merece le dan muerte natural". 101 "Los ritos y ceremoniales puedo decir que tienen una casa que llaman la del sol, cubierta de lumeria de varios colores adonde ofrecen grandes riquezas de mantas y joyas, y algunas piedras preciosas, y obedecen con cuidado y puntualidad, los mandatos de sus capitanes", afirmava, ainda, o depoente, parecendo sugerir uma conexão entre os templos e a autoridade dos chefes; e os que não os atendiam, "lo dan su pena de matarlos a toda la generación, ansi viven muy en paz y quietud y muy pacíficos". ${ }^{102}$

99 Informaciones que, por mandado de la Audiencia de Quito, se hicieron para enviar a S.M., 5 de janeiro de 1631, AGI, Quito, leg. 88, n. ${ }^{\circ}$ 38, ff. 16-16v. Informe de Gabriel Machacón, San Pedro de Alcalá del Río Dorado, Quijos, 25 de novembro de 1630, AGI, Quito, leg. 88, n. $^{\circ} 38$, f. $16 \mathrm{v}$.

100 Idem.

101 Informaciones que, por mandado de la Audiencia de Quito, se hicieron para enviar a S.M., 5 de janeiro de 1631, AGI, Quito, leg. 88, n. ${ }^{\circ}$ 38, ff. 18-20. Informe de Juan de Palácio, San Pedro de Alcalá del Río Dorado, Quijos, 26 de novembro de 1630, AGI, Quito, leg. 88, n. ${ }^{\circ} 38$, f. $18 \mathrm{v}$.

102 Idem. Igualmente positiva era a imagem tecida pelo depoimento de Tomás Lorenzo de Guirón, também vizinho da cidade de San Pedro de Alcalá, assegurado em sua experiência como integrante das expedições lideradas por Gabriel Machacón aos Avijiras e Omaguas. Em seu testemunho, reconhecia a autoridade dos chefes nativos: "Los indios de las provincias los más son vestidos y su vestidura es muy pintada de pincel de muy varias colores; es gente de 
Para reforçar seu memorial, Gabriel Machacón integrou o depoimento de Don Cristóbal Ehende, cacique principal do pueblo de sua encomienda, índio ladino na língua do Inca e em espanhol. Não havia dúvidas sobre a abundância de mantimentos do lugar, diz o cacique, dada a fartura de frutas e de "maní, frijoles y muchas raíces que les sirven de pan y vino". Assinala ainda que os índios Avijiras e Omaguas "andan muy bien vestidos, es gente muy curiosa y de gobierno, viven sujetos a su cacique y señorío, viven en barrios muy grandes, las casas son grandísimas y muy fuertes cubiertas con mucha curiosidad". Termina com referência à atuação de certo jesuíta que, durante a expedição de Alonso de Miranda, batizou muitos índios das terras baixas: "Será bien que se conquiste estas tierras y provincias por haver mucha gente entre los barbaros aver muchos christianos de los que quedaron bautizados". ${ }^{103}$

Em todo o caso, descrever os índios como homens com princípios de vida em polícia e costumes não tão bárbaros quanto se supunha era uma forma alternativa de alcançar o apoio da Coroa para capitulações de conquista. Descrições que contradiziam as divulgadas, em outros momentos, por missionários que preferiam pintar os índios como sem fé, sem lei e sem rei, de modo a justificar ao Conselho das Índias sua ação evangelizadora e o pedido de recursos para a missão.

Os índios do entorno da cidade de Borja seguiram sendo acossados pelos colonos, em expedições tituladas como de "pacificação" e que contavam com o apoio de grupos amigos. O governador Diogo Vaca de Vega, por exemplo, coordenou sucessivas entradas, tendo uma delas sido dirigida aos Cocamas, movida por índios Maynas que haviam acusado seus rivais de praticarem hostilidades contra os índios amigos dos espanhóis. ${ }^{104}$ Entrada que não terá sido de pequena monta, segundo diz um informante, pois contava com 50

grande gov.o porque conocen a sus capitanes y los obedecen en particular a sus caciques, son castigados con rigor y aun les dan la muerte al que lo merece; viven con grande gov.o; son ingeniosos; las mujeres son muy honestas y trabajadoras, ylan, y tejen para sus maridos, y hijos; son caritativas" (Informaciones que, por mandado de la Audiencia de Quito, se hicieron para enviar a S.M., 5 de janeiro de 1631, AGI, Quito, leg. 88, n. ${ }^{\circ} 38$, ff. 24-25. Informe de Tomás Lorenzo de Guirón, San Pedro de Alcalá del Río Dorado, Quijos, 25 de novembro de 1630, AGI, Quito, leg. 88, n. ${ }^{\circ}$ 38, f. 24).

103 Informaciones que, por mandado de la Audiencia de Quito, se hicieron para enviar a S.M., 5 de janeiro de 1631, AGI, Quito, leg. 88, n. ${ }^{\circ}$ 38, ff. 26-26v. Informe de Don X.toval Ehende, cacique principal, San Pedro de Alcalá del Río Dorado, Quijos, 25 de novembro de 1630, AGI, Quito, leg. 88, n. ${ }^{\circ} 38$, f. 26.

104 Información de los méritos y servicios del capitán don Diego Vaca de Vega, Borja, 4 de junho de 1621, AGI, Patronato, leg. 148, n. ${ }^{\circ}$ 1, ramo 3, f. 3v. 
espanhóis, 400 índios e 70 canoas. ${ }^{105}$ Também foi referido que o cabo da entrada não pôde frear o ânimo dos Maynas de tomar vingança contra os Cocamas que, como puderam verificar em seus assentamentos, praticavam rituais antropofágicos com os cativos capturados entre os índios cristãos. Indicando como os resultados podiam extrapolar as justificativas iniciais, foi trazido a Borja um número importante de "peças", que incluíam indivíduos das nações "Xeberos, Cocamas, Omaguas, Viarinal, Vanivae y Aguanos, y otras muestras". ${ }^{106}$

Os efeitos deletérios dessas entradas aos índios das cercanias de Borja foram assinalados pelo padre Figueroa, em sua Relación de 1661: "Sacábase mucha gente de varias provincias, yendo en armada, cogiéndola y trayéndola en gruesas tropas que repartían entre los soldados y vecinos, que son las que llaman "piezas". ${ }^{107}$ Entre os pretextos utilizados pelas expedições, alegava-se que pretendiam chamar de volta os índios cristãos que haviam "apostatado" e desertado para a floresta, índios por essa razão chamados de cimarrones. Resultava, no entanto, que os soldados não poupavam nação alguma que encontravam pela frente, de quem capturavam quantos cativos podiam. De tais violências se seguiam grandes mortandades entre os índios, "pues dentro de pocos días apenas quedaban vivos la décima parte". ${ }^{108}$

A distribuição dos índios capturados pelas entradas em encomiendas estava prevista nas disposições legais que organizavam o governo de Maynas. Antes de tudo, é preciso ter em conta que as capitulações garantiam encomiendas aos vecinos espanhóis que participassem da conquista do vale do rio Marañón. Como já referido, o título de governador e as capitulações de Diego Vaca de Vega, expedidos em Callao, em 1618, garantiam a "conquista" dos índios ribeirinhos, nomeadamente dos Maynas, Cocamas e Jívaros, mas também de outros que fossem encontrados. Também garantiam ao governador jurisdição para encomendar índios dessas conquistas "en las personas y soldados que con él fueron a ellas, según sus méritos y servicios, por tres vidas"; que em cada nova cidade que se povoasse fosse assinalada uma encomienda para a Coroa e uma para o governador (esta última por quatro vidas); que os moradores das regiões adjacentes podiam participar das entradas e ser premiados com encomiendas; e que as terras, solares e cavalarias fossem repar-

105 Testimonio del P. Predicador Fray Francisco Ponce de León vicario provincial, Borja, 5 de junho de 1621, AGI, Patronato, leg. 148, n. ${ }^{\circ} 1$, ramo 3, f. $8 \mathrm{v}$.

106 Ibidem, f. 9.

107 Figueroa, 1904 [1661]: 11.

108 Idem. 
tidas pelo governador entre os vizinhos conquistadores e povoadores, conforme as instruções de novas povoações de 1573.109

Retratar certo grupo indígena como "bárbaro" permitia justificar pedidos de capitulações e de concessões de encomiendas. A alegação de que os Motilones hostilizavam os índios de paz, a quem capturavam, comiam ou insuflavam a que retornassem às práticas idólatras, era motivo para que o vice-rei de Lima capitulasse, em 1611, com Alvaro Enríquez del Castillo, morador de Chachapoyas, a conquista daquele gentio. Entre as promessas de prêmios estavam os títulos de governador e capitão e a faculdade de conceder encomiendas em um vasto e impreciso território, que podia abarcar todo o Marañón até o Brasil. ${ }^{110}$

As supostas hostilidades promovidas pelos Motilones contra os índios cristãos não eram a única justificativa alegada por Alvaro Enríquez del Castillo: havia ainda a suposição de que a região onde viviam "tiene oro en los ríos", além de ser a terra fértil e propícia à criação de gado: "estos motilones", fazia constar o capitão em seu memorial, "tienen mucho ganado de bacas y yeguas de las que allí dejaron los españoles. Es tierra fértil como España, dase en ella trigo y melones, y ubas, y todos los frutos de Castilla". Tudo isso com o agravante de que se tratavam de índios caribes: "a los yndios pasan a cuchillo; y se los comen por comer carne humana". De pouco atenuante servia, nesse caso, o fato de os Motilones manifestarem certo apreço pelas imagens cristãs, quando havia notícia de que as roubavam das igrejas. ${ }^{111}$

As incursões - reais ou supostas - movidas por certos grupos com o objetivo de pilhar seus vizinhos (e, mais tarde, os pueblos missionários) faziam reiterar as descrições de teor negativo. Ao resenhar os relatos do jesuíta padre Gaspar de Cugía a respeito de sua viagem que, em 1643, passou até as juntas do rio Marañón e do Huallaga para visitar os Cocamas, o historiador José Jouanen extrai que estes últimos, que viviam no vale do rio Ucayali, eram temidos "por sus piraterías y depredaciones" nos rios amazônicos, pois "salían de sus tierras casi todos los años formando unas armadillas de cua-

109 “Título de gobernador" [a Diego Vaca de Vega, Príncipe de Esquilache, Callao, 17 de setembro de 1618], Revista de archivos y bibliotecas nacionales, 2/3 (Lima, 1899): 180-187.

110 Relación que hace a S.M. el capitán Alvaro Enríquez del Castillo de la jornada de los Motilones, y el río grande del Marañón y sus provincias (minuta del Fiscal), Lima, 24 de abril de 1611, AGI, Lima, leg. 141.

111 Relación de la jornada de los motilones y río Grande del Marañón, y sus provincias que da el capitán Alvaro Enríquez del Castillo, Lima, 24 de abril de 1611, AGI, Lima, leg. 141, f. 2 . 
renta a cincuenta canoas, para matar y robar cuanto encontrasen". ${ }^{112}$ Entre os colonizadores ibéricos, descrever os índios como corsários e piratas, como salientou Monteiro, era uma forma de justificar a captura e o serviço pessoal, e não propriamente uma descrição de um comportamento. Basta lembrar o modo como os portugueses referiam-se aos chamados "tapuias" como "gentio de corso" e nômades, sendo certo que muitos possuíam assentamentos estáveis e diversos cultivos. ${ }^{113}$

Do mesmo modo, uma "Relación” do cura de Borja, Diego Nuñes Castaño, lembrava em 1623 que o motivo inicial alegado por Vaca de Vega para capitular a conquista dos Maynas era o de que as cidades espanholas da região eram alvo de incursões do referido gentio. ${ }^{114}$ Pedro Vaca de la Cadena, filho de Diego Vaca de Vega e seu sucessor no posto de governador de Maynas, ao referir os méritos de seu pai em um informe enviado em 1629, menciona que a efetiva redução dos índios e sua distribuição aos encomenderos ocorreu após uma revolta decorrente de que os espanhóis haviam dado morte a certo cacique dos índios de paz, que prontamente fugiram da região. Novas expedições reuniram até oito mil almas, as quais foram encomendadas por Diego Vaca de Vega a 40 colonos espanhóis. ${ }^{115}$

Apesar do difundido que estava o discurso da guerra, as propostas de entradas puramente militares tendiam a ser recebidas com reservas pelo Conselho das Índias. Em Cédula de 1687, a Coroa lembrava o princípio da escolha voluntária que regia a incorporação dos índios à dominação espanhola e ressaltava a importância de reduzir os Jívaros, sendo sua terra promissora em descobrimentos auríferos: "encargándolos se juntase con la suavidad y buen modo que se debía, sin hazerles vejaciones, ni intentar que se redujesen con violencia, ni por fuerza de armas". ${ }^{116}$

112 Jouanen, 1941: 379. Referindo-se aos perigos do rio Napo, o missionário padre Pablo Maroni escrevia: "En este río a más de estar casi de todo despoblado con poca o ninguna esperanza de avío, está sitiado de varios infieles piratas, reos de muchas muertes" (Pablo Maroni ao presidente da Audiência de Quito, Colégio Máximo de Quito, 15 de junho de 1733, AGI, Quito, leg. 158, f. 543).

113 Monteiro, 1994: 45-46 e 52-53; 2001: 65.

114 Relación de Diego Nuñes Castaño cura doctrinero que a sido de los españoles y naturales de la ciudad de San Francisco de Borja, en la provincia de los Maynas, 1623, AGI, Quito, leg. 11, ramo 3, n. ${ }^{\circ}$ 37, ff. 1-1v.

115 Relación dada por D. Pedro Vaca de la Cadena governador de la provincia de los Maynas, de abril de 1629, AGI, Quito, leg. 11, ramo 3, n. ${ }^{\circ}$ 37, ff. 1-1v.

116 Real Cédula al Presidente y oidores de la Audiencia de Quito, Madri, 26 de janeiro de 1687, AGI, Quito, leg. 210, lib. 5, f. 222. 


\section{OS ENCOMENDEROS E AS IMAGENS DOS ÍNDIOS}

Como quer que seja, as imagens produzidas pelos colonos espanhóis a respeito dos índios amazônicos continuavam a justificar o apresamento e o serviço pessoal. E embora o mito do El Dorado tenha recebido a atenção de numerosos historiadores, ainda não foi suficientemente sublinhado o modo como essas imagens da Amazônia podiam justificar não apenas as explorações em buscas de metal precioso, como também — e principalmente - a captura dos índios ribeirinhos para o serviço dos colonos das cidades adjacentes. ${ }^{117}$

A emergência do mito do El Dorado, em todo o caso, é bastante conhecida. El Dorado era o termo utilizado pelos espanhóis para referir-se a toda a região supostamente aurífera por explorar, localizada ora no Marañón, ora em Cumaná, ora em Tierra Firme, ora na Guayana, ora no Rio da Prata. ${ }^{118}$ Desde memoriais que solicitavam ao Conselho das Índias a capitulação para a conquista e pacificação de determinados grupos indígenas e a exploração das riquezas minerais que supostamente existiam em terras amazônicas, até títulos de governador que abarcavam imensas regiões, em grande medida incógnitas, nas quais se supunha existir metal precioso em abundância, o termo $E l D o$ rado reaparecia como sinônimo de província onde se acreditava existirem poderosas riquezas, cuja localização e extensão eram ainda ignoradas pelos conquistadores. ${ }^{119}$

117 Sucedeu de modo similar nos domínios lusitanos: a pretexto de pesquisa por metais e pedras, os colonos voltavam de suas expedições com "peças". Holanda, 2000: 56.

118 Espinoza Soriano, 2007: 42.

119 O termo, contudo, inicialmente, esteve circunscrito a uma situação bem concreta. À época da fundação de Quito, em 1534, deram-se a conhecer, de um modo vago, notícias sobre a existência de um cacique que residia nas proximidades da lagoa Guatavitá (localizada entre as atuais cidades de Bogotá e Tunja, na Colômbia), que tinha o costume de cobrir seu corpo com uma camada de ouro em pó para realizar certas cerimônias religiosas (Hemming, 1979: 53-58). Sebastián de Benalcázar, fundador daquela cidade, orientou a que os espanhóis obtivessem notícias mais consistentes a respeito dos caciques Chibchas que realizavam celebrações com metal precioso na lagoa Guatavitá (Espinoza Soriano, 2007: 45). Ao que se sabe, a primeira referência ao "Homem Dourado" foi obtida ainda em 1534. Luis de Daza encontrou em Latacunga (atual Equador) um índio chamado Muequetá, que por ordem do cacique Bogotá, de Cundinamarca, dirigira-se a Quito para solicitar auxílio militar contra seus inimigos. O índio Muequetá, entre as informações que forneceu a respeito do seu país, deu conta de que nele havia muito ouro, e mencionou a cerimônia do Homem Dourado, que na opinião do cronista Antonio de Herrera y Tordesillas "ha sido causa de haver muchos emprendido aquel descubrimiento del Dorado, que hasta aora parece encantamento" (Herrera y Tordesillas, 1728 [1615], vol. 5, década 5, lib. 7, cap. 14: 179. Gandía, 1946: 117). Segundo informações apuradas por frei Pedro Simón (1891 [c. 1627], vol. 2, caps. 1 e 2: 242-243 e 245), Benalcázar ouviu que o referido cacique Bogotá ou Dourado resolvera punir uma índia adúltera com 
$\mathrm{O}$ que comumente se atribui à credulidade e à falta de senso de realidade de conquistadores e missionários era, antes de tudo, parte de um processo de negociação entre os autores desses informes e as autoridades reais; negociação que envolvia interesses mais palpáveis, como eram a solicitação de auxílio a entradas exploratórias; as promessas de mercês de governações de vastos territórios; e a faculdade para encomendar os índios que ali habitavam. ${ }^{120}$ Assim, a partir de 1540, vários colonos passaram a instalar-se nos vales dos rios Pastaza e Palora. Desde Quijos, os colonos enviavam expedições denominadas correrías, com vistas a capturar índios para o serviço pessoal. Quatro cidades, impulsionadas pela extração do metal precioso, foram como que portas de entrada para a exploração da Amazônia ocidental. Eram elas Chachapoyas, Huánuco, Moyobamba e Jaén de Bracamoros. ${ }^{121}$

O mito do El Dorado continuou a ser mobilizado por colonos espanhóis em seus projetos para as terras baixas da Amazônia, de onde esperavam toda

dar-lhe de comer, em uma festa, as partes íntimas de seu amante; a índia precipitou-se na lagoa Guatavitá com a sua filha; o cacique, arrependido, passou a seguir o conselho dos seus sacerdotes e a realizar oferendas de ouro e pedras preciosas na mesma lagoa, em um ritual em que devia apresentar-se com o corpo coberto de uma substância pegajosa em que fazia aderir uma fina camada de ouro em pó (Bayle, 1943: 25-27. Gandía, 1946: 111). Posteriormente, o célebre cronista Oviedo, em sua Historia general y natural de las Indias, recolheu mais detalhes sobre El Dorado: "este cacique o rey dicen los indios ques muy riquíssimo e grand señor, e con cierta goma o licor, que huele muy bien, se unta cada mañana, e sobre aquella unción assienta o se pega el oro molido o tan menudo como conviene". A razão disso seria "porque le paresçe a él que traer otro cualquier atavío es menos hermoso, [...] es grosería e cosa común". Enfim, "queda toda su persona cubierta de oro, desde la planta del pie hasta la cabeça, e tan resplandesçiente como suele quedar una pieça de oro labrada de mano de un gran artífice" (Fernández de Oviedo y Valdés, 1855 [1548], t. 4, lib. 49, cap. 2: 383. Bayle, 1943: 19-20).

120 Lorandi, 1997: 187, 209 et passim. Scott, 2009: 109-113.

121 Espinoza Soriano, 2007: 66. O nome El Dorado foi aplicado a distintas fontes de ilusão que em nada se relacionavam com a primitiva cerimônia do cacique Dorado, buscado por Benalcázar em fins dos anos 1530 (Gandía, 1946: 125-128). Gonzalo Díaz de Pineda, por encargo de Francisco Pizarro, levou a cabo uma expedição ao país dos Quijos, a partir de 1534. Essas regiões ficaram conhecidas como La Canela, devido às árvores que ali existiam, mas também passaram a ter seu ouro explorado, especialmente em Macas. Em 1539, Francisco Pizarro nomeou seu irmão Gonzalo para explorar o misterioso país de La Canela e, se possível, verificar a existência do El Dorado. A famosa expedição partiu de Cuzco em direção ao vale do rio Amazonas. Em 1542, Gonzalo Pizarro decidiu retornar, ao passo que Francisco de Orellana prosseguiu a viagem até a foz do grande rio (Hemming, 1979: 108-114). A partir de 1547, Juan Pérez de Guevara percorreu o rio Huallaga em busca de uma reencarnação do El Dorado denominada Ruparrupa ("país ardente"), um império de riquezas inauditas, perseguido também desde Chachapoyas e Huánuco (Espinoza Soriano, 2007: 62). Sobre a busca do El Dorado nos llanos de Mojos, ver: Livi Bacci, 2012: 41 e ss. 
a sorte de vantagens e, em especial, o controle da força de trabalho indígena. Em 1613, o já mencionado o capitão Alvaro Enríquez del Castillo, morador da cidade de Chachapoyas, no Peru, ao descrever a província de Motilones, entendia que a região era um novo El Dorado, assim pela quantidade de metal precioso ali estimada, como pelos índios que podiam servir como trabalhadores aos colonos: "la tierra es rica de plata y oro larga con muchas poblaciones”. Desse modo, a colonização das províncias mais próximas poderia render à Coroa até "dos millones de renta de quintos y otros aprovechamientos", e passando adiante, mais para o interior, até seis milhões, "porque mucho oro hay tierra adentro y muchos números de indios que lo saquen y que todos ellos me quieren bien y han oído mi nombre". ${ }^{122}$

Enríquez del Castillo havia proposto, em 1611, que se lhe fosse confirmada a capitulação da conquista dos índios da Amazônia (sem custo algum para a Real Fazenda), nomeadamente dos Motilones, Tabalosos e os do rio Marañón, com a alegação de que esses nativos haviam promovido hostilidades contra os índios cristãos que já serviam em encomiendas. ${ }^{123}$ Em seu arrazoado, o suplicante afirmava que os índios lhe tinham tanta estimação e confiança que "muchos an salido de la tierra adentro a verme y traído presas". ${ }^{124} \mathrm{O}$ vice-rei terá recebido semelhantes propostas com cautela e suspeição, chegando mesmo a rechaçar os requerimentos anteriores, aconselhado por outras pessoas principais daquela comarca, que haviam desmentido as notícias de Enríquez del Castillo. ${ }^{125}$

As terras baixas amazônicas seguiam sendo vistas como prováveis depositárias de riquezas, se não as do El Dorado, pelo menos as da abundante e potencial mão de obra indígena. Em todo o caso, as notícias de minas eram incertas, e o poder central as via com ceticismo. Em informe de 1629, ao descrever os índios e as terras de Maynas, um fiscal da Audiência de Quito rechaçava a possibilidade de que ali houvesse minas: "no se ha entendido tengan minas de oro, plata ni otros metales". ${ }^{126}$ Em fins dos anos 1630, o tema

122 Carta del capitán Alvaro Enríquez del Castillo, Callao, 12 de abril de 1613, AGI, Lima, leg. 141, f. 2v.

123 “... han quemado muchos pueblos, chacras y casas, y llevado y metido la tierra adentro muchos christianos, y otros se les han pasado, por ser gente necesitada y librarse de tasas, mitas y otras obligaciones, a vivir con libertad sin tener quien los gobierne ni corrija, y los unos y los otros an seguido sus antiguos errores e idolatrías" (Méritos de Alvaro Enríquez del Castillo, 1611, AGI, Lima, leg. 141, f. 1).

124 Idem.

125 Ibidem, f. 1v.

126 Carta de Antonio de Morga, presidente de la Audiencia de Quito, a S.M., 15 de abril de 1629, AGI, Quito, leg. 11, ramo 3, n. ${ }^{\circ} 37$, f. 2v. 
parece haver retornado à pauta daquele tribunal, que dessa vez emitiu parecer favorável ao envio de armadilhas a Maynas, com o que "logrará el patrimonio Real la provincia mas abundante de tesoros y ricos minerales que aseguran las tradicciones antiguas". ${ }^{127}$ Do mesmo modo, o piloto Alonso Bacas, inquirido em 1677 pela Casa de la Contratación de Sevilha a informar sobre o que sabia a respeito da Amazônia, renovava o mito do El Dorado ao dar conta de que ouvira, por fontes seguras, ser certa a existência, mais para o interior, de uma região "muy rica de oro, y plata en que havía muchas minas abiertas", e que para buscá-la os portugueses haviam cuidado de avançar seus estabelecimentos no Pará. ${ }^{128}$

Memoriais que propunham capitulações com a Coroa para a conquista da Amazônia frequentemente referiam a riqueza do espaço amazônico e as potencialidades das populações indígenas, como força de trabalho e nova cristandade. É assim que, em 1630, fez subir ao Conselho das Índias Vicente de los Reyes Villalorios, governador de Quijos, um memorial em que solicitava autorização para a conquista do vale do rio Marañón. As mercês e privilégios que requeria como prêmio, no entanto, não podiam deixar de ser vistas em Madri como exorbitantes e contrárias ao modo como as Índias eram administradas, pois incluíam o governo perpétuo de todas as províncias que fossem conquistadas; a jurisdição para fundar vilas, nomear para cada uma delas um lugar-tenente, alcaides e regidores e conceder encomiendas por três vidas; e o soldo anual de três mil ducados. ${ }^{129} \mathrm{O}$ papel apresentava, naturalmente, uma visão idealizada do espaço e das populações da Amazônia, referida como "El Dorado", "que es fertil de oro y de mantenimientos de frutas". ${ }^{130}$ A atitude

127 Carta del presidente y oidores de la audiencia de Quito, a S.M. informando de la conveniencia de que se de licencia al capitán Melchor del Mármol para hacer la reducción de los indios Jíbaros, 20 de maio de 1678, AGI, Quito, leg. 14, ramo 8, n. ${ }^{\circ}$ 34, f. 1.

128 Relación de lo que parece por los ynformes que a remitido la Casa de la Contratación, Tomás Miluti [post. a 1677], RAH, Jesuitas, t. 187, doc. 23, f. 235.

129 Informaciones que, por mandado de la Audiencia de Quito, se hicieron para enviar a S.M., 5 de janeiro de 1631, AGI, Quito, leg. 88, n. ${ }^{\circ}$ 38, ff. 9-10. Memorial de Vicente de los Reyes Villalorios, governador de Quijos, 19 de janeiro de 1630, AGI, Quito, leg. 88, n. ${ }^{\circ} 38$, ff. $9 \mathrm{v}-10$.

130 Ibidem, f. 9. Premiação igualmente exorbitante aos olhos da Coroa solicitara Alonso de Miranda que, após realizar uma entrada aos Omaguas em 1621, requereu autorização para fundar cinco cidades, o título de marquês e 20 mil ducados de renda. Uma Real Cédula, expedida no mesmo ano, rechaçou o pedido como despropositado, pois o título de marquês nem mesmo existia no vice-reino do Peru, sendo algo alheio à razão introduzi-lo, "pues podría ser que todo el interés de dichos descubrimiento y poblaciones no alcanzan para semejantes premios" (Informaciones, AGI, Quito, leg. 88, n. ${ }^{\circ}$ 38, ff. 10v-11. Real Cédula à Audiência de Quito, Madri, 7 de junho de 1621, AGI, Quito, leg. 88, n. ${ }^{\circ} 38$, f. 11). 
desconfiada de Madri em parte decorria da enxurrada de memoriais que, em meados do século XVII, apareciam naquela Corte, um espaço que se havia convertido —na observação de John H. Elliott - em "an irresistible magnet to petitioners, place-hunters, and picaros from all over Spain". ${ }^{131}$

Se o mito do El Dorado podia ser retomado por aqueles que esperavam convencer a Coroa a apoiar seus projetos de exploração das terras baixas, era amplamente reconhecido que, se faltassem as riquezas minerais, o acesso à mão de obra indígena compensaria os esforços de uns e outros. A concessão de encomiendas era um requisito constante já nos primeiros memoriais que pretendiam capitular com a Coroa a conquista de territórios amazônicos. Em 1568, certo Pedro Maraver de Silva logrou capitular uma licença para fundar nas terras dos índios Omaguas e Omeguas e em El Quinaco uma Nova Estremadura. Para tanto, comprometeu-se a recrutar 500 homens naquele ano (100 deles casados e com filhos) e mais 500, quatro anos mais tarde. Encarregou-se, ainda, de fundar três cidades, às quais deveria prover, inicialmente, com 100 cavalos, 100 éguas, 500 vacas, 100 ovelhas, 200 porcos e outra centena de cabras. Se tudo corresse como esperado, as mercês previstas incluíam o cargo de governador de Nova Estremadura por duas vidas, com salário anual de $100 \mathrm{mil}$ maravedis e a faculdade de nomear alcaides, juízes, conselheiros e corregedores e de conceder aos colonos quantas encomiendas julgasse conveniente. ${ }^{132}$

O governo de Quijos, às margens do rio Caquetá, identificado pelos portugueses como Japurá e, segundo se acreditava, rico em metal precioso, compunha-se de três cidades, Archidona, Ávila e Baeza, e quatro partidos, Sucumbíos, Macas, Quijos e Jívaros. A cidade de Archidona era a capital. ${ }^{133}$ Os colonos consideravam que as encomiendas eram indispensáveis à sua permanência naquela fronteira. Na opinião do governador Joseph González, não era tanto por razões econômicas que elas eram importantes, pois a maioria dos encomenderos contava com 10, 20 ou 30 índios, com os quais mal podiam manter-se. Mas por razões defensivas: em uma região que padecia contínuas invasões de índios independentes, os colonos não apenas ficavam obrigados a defender aquela jurisdição, como podiam contar com as armas dos índios amigos para fazê-lo. ${ }^{134}$

131 Elliott, 1977: 170.

132 Capitulación con el capitán P.o de Silva sobre el descubrim.o, y pobl.on de las provincias de Omagua y Omeguas y el Quinaco y los demás pay.s, Aranjuez, 15 de maio de 1568, AGI, Indiferente General, leg. 416, lib. 4, ff. 1-6v. Sobre as implicações geopolíticas dessa capitulação, ver: López Ruiz, 1973.

133 Oberem, 1980: 96-100. Gómez González, 2014: 162 e ss.

134 El gobernador de la Provincia de Quijos y Macas, Joseph González, al rey, Macas, 17 de março de 1722, AGI, Quito, leg. 137, n. ${ }^{\circ}$ 32, f. 291. Os moradores de Quijos alegavam 
Os colonos pretextavam que capturar índios "bárbaros" e distribuí-los em encomiendas era uma forma de reduzi-los à polícia cristã. $\mathrm{O}$ cabildo secular de Cartagena de Indias, já em 1623, chamava a atenção para os índios caribes que habitavam os rios Marañón e Amazonas, com vistas a legitimar as entradas em busca de cativos indígenas que, uma vez convertidos em escravos, se tornariam também cristãos e, com isso, ganhariam o caminho da salvação. ${ }^{135}$ Quando faltavam trabalhadores indígenas para os empreendimentos dos colonos fronteiriços, os mais variados pretextos podiam servir para capturar os naturais das terras baixas. Verificada, nos inícios do século XVII, a escassez de trabalhadores para as minas de Cuenca, cujos recursos eram insuficientes para comprar negros, sugeria um oficial espanhol a utilização dos Jívaros - cerca de quatro mil almas viviam naqueles arrabaldes - como trabalhadores forçados, o que se justificava por serem "gente muy traydora que comen carne humana". ${ }^{136} \mathrm{O}$ visto do fiscal se limitou a recomendar a conquista "por medio de religión y de la pacificación", salvo se realmente se tratassem de índios rebelados e caribes, mas, em todo o caso, a expedição não deveria correr à custa da Real Fazenda. ${ }^{137}$

Os colonos também podiam alegar que determinado grupo obstruía o caminho e os contatos com os índios amigos que, no seu entender, manifestavam disposição para aceitar a fé cristã. O governador de Maynas, Diego Vaca de Vega, lembrava que recentemente uma expedição comandada por seu filho fora atacada ao voltar do rio Pastaza, com a perda de oito índios. Essas ofen-

que a província estava sob constante ameaça dos "bárbaros", e que a encomienda era a única forma de garantir o recrutamento de tropas e a mão de obra necessária à manutenção dos colonos. Em 1761, por exemplo, em um informe de Juan Romualdo Navarro consta que os índios ainda não reduzidos "hacen repentinas invasiones en nuestros pueblos, viviendo esas gentes en un continuo sobresalto" (Idea del reino de Quito, Juan Romualdo Navarro, ouvidor da Audiência, Madri, 12 de fevereiro de 1761, AGI, Quito, leg. 223).

135 Carta del cabildo secular de Cartagena de Indias sobre los indios caribes que habitan en los ríos Marañón y Amazonas, y la posibilidad de llevarlos a aquella provincia como esclavos, 14 de dezembro de 1623, AGI, Santa Fe, leg. 63, n. ${ }^{\circ}$ 50, f. 1 . Em áreas fronteiriças, a permanência da encomienda era justificada — como se pode ler em uma carta do cabildo de Popayán - com a alegação de que os índios eram bárbaros, e de que a instituição, além de ser uma forma de civilizá-los, atendia ao bem comum ao promover o cultivo das terras, fomentar os ingressos da Real Hacienda e prontificar a defesa das fronteiras (El cabildo de la ciudad de Popayán informa a VM la utilidad que puede seguirse al común de ella, si las encomiendas de su jurisdicción han de correr en la conformidad que tenían antes, 28 de julho de 1727, AGI, Quito, leg. 139, f. 1v).

136 Carta de Martín de Ocampo a S.M., Cuenca, 20 de abril de 1606, AGI, Quito, leg. 26, n. ${ }^{\circ} 56$, f. $1 \mathrm{v}$.

137 Visto do Fiscal do Conselho das Índias [s.d.], AGI, Quito, leg. 26, n. 56. 
sas não podiam ser toleradas: "su exceso ha quitado mi escrúpulo; pues sin haberles hecho mal, me le han hecho tan grande que me obliga a procurar castigarlos y permita hacerles guerra fuego y sangre". Tanto mais porque ficavam prejudicadas as negociações que os espanhóis mantinham com vários grupos daquela fronteira: "tengo reduzidas quatro provincias maynas, pastaças, xeberos, y moronas, adonde ay mucha gente y reciben bien el querer ser cristianos, y se an bautizado muchos. La de los cocamas es la mayor, y me a dado sumo cuidado". 138

Os encomenderos da jurisdição da Audiência de Quito sofreram revezes importantes durante o século XVII, com a incorporação de tributários ao patrimônio real ou a concessão de vacantes aos peninsulares mais destacados. Excluídos dos cargos da Audiência, os encomenderos mantiveram o domínio dos cabildos e de certos postos militares, mas os ofícios de corregidores e oficiales reales também passaram aos recém-chegados. Estratégias matrimoniais e a concentração dos seus índios nas obrajes puderam oferecer uma compensação econômica para a erosão do seu poder político. Pela década de 1650, quando aproximadamente metade dos encomenderos residiam fora dos arredores da capital, cerca de $30 \%$ dos tributários estavam sob controle real direto. ${ }^{139}$ No fim do século, as epidemias que assolaram a costa ceifaram um terço das vidas dos trabalhadores indígenas, o que somado à competição com têxteis franceses e à retração dos mercados andinos, levaram as obrajes de Quito —onde boa parte dos índios de encomiendas eram empregados - à depressão. Ainda nas primeiras décadas do século XVIII, contudo, houve um movimento populacional em direção a Cuenca, ao sul de Quito, cidade que se tornou um importante polo de manufaturas de têxteis de algodão. ${ }^{140}$

A encomienda era retratada como uma instituição benéfica não apenas para os particulares, como também para a Coroa, que garantia o domínio e a segurança sobre vastos territórios e desterrava a barbaridade dos índios em favor de sua civilização e evangelização. Tais os argumentos utilizados pelo governador de Quijos e Macas, em 1722, contra a possibilidade de que Madri proibisse novas concessões de encomiendas aos colonos daquelas cidades. ${ }^{141}$ A dar crédito ao que escreviam as autoridades fronteiriças, índios indepen-

138 Informe de Diego Vaca de Vega, 1 de dezembro de 1629, AGI, Quito, leg. 11, ramo 3, n. ${ }^{\circ}$ 37. Sobre as expedições movidas pelos moradores de San Francisco de Borja, Anda Aguirre, 1995: 45.

139 Ortiz de la Tabla Ducasse, 1993: 116-117 et passim.

140 Andrien, 1995: 41.

141 Informe do governador de Quijos y Macas, Joseph González, 12 de março de 1722, AGI, Quito, leg. 137, f. 2v. 
dentes continuavam a atacar os pueblos cristãos das jurisdições de Quijos e Macas. ${ }^{142}$ A instituição da encomienda era importante, segundo procurava inculcar o governador, porque podia propiciar, ainda que de modo insuficiente, o recrutamento dos milicianos encomenderos, obrigados à defesa do país: "los encomenderos de toda la provincia de Quijos [...] están reducidos al número de diez, y no pudiendo ser bastantes estos, [he tenido que] conducir a mi costa otros hombres con armas pasando con este corto cuerpo de gente a las tierras que ocupan los enfieles", referia sobre uma entrada ao rio Napo, movida em agosto de $1720 .{ }^{143}$

O governador de Quijos e Macas, aliás, estava empenhado em justificar a permanência das encomiendas, diante da resolução da Coroa em reintegrar à sua Real Fazenda as que se tornassem vagas em razão da morte de seus titulares, como expressara nas Reais Cédulas de 23 de novembro de 1718 e 12 de julho de $1720 .{ }^{144}$ Outro informe do mesmo Joseph González assinalava

142 Os encomenderos de Quijos recorriam ao tema da tradicional animosidade entre os índios amigos e os índios "bárbaros", como forma de justificar a manutenção do serviço dos seus tributários. O serviço militar dos encomenderos seria indispensável contra os ataques de certos grupos indígenas, entre os quais Oberem (1981: 368-370 e 373) supõe estivessem os Arianas, que juntamente com os Yetés eram parcialidades Omaguas que haviam residido no rio Napo até meados do século XVII. As hostilidades dos encomenderos, segundo o mesmo estudioso, levaram a que, pela década de 1630, boa parte dos Omaguas do rio Napo resolvesse migrar e reunir-se aos seus parentes que viviam no vale do Amazonas. Os jesuítas padres Acuña e Maroni, em momentos distintos, teceram observações sobre o processo de migração dos Omaguas e suas relações conflituosas com os moradores de Quijos. Acuña notou que os Omaguas que viviam no rio Napo "estuvieron de paz, no ha muchos años en el gobierno de los Quijos, de donde obligados del mal tratamiento que se les hacía, se dejaron venir el río abajo, hasta encontrar con la fuerza de los de su nación". O mesmo jesuíta atribuía ao contato com espanhóis o "adiantamento" em que se encontravam os grupos Omaguas que pôde visitar, dado que os recém-chegados haviam introduzido, entre seus parentes do Amazonas, algo do que haviam aprendido em Quijos, e "les pusieron en alguna policía" (Acuña, 2009 [1641]: 124). Quase um século mais tarde, o padre Maroni acrescentou alguns detalhes ao que havia referido seu colega Acuña: os encomenderos de Baeza e Quijos trasladaram alguns Omaguas para o vale do rio Sunu, onde se aproveitavam deles "en la labor de las minas". Mas os índios se levantaram, deram morte a um encomendero e se retiraram, alguns deles, às cabeceiras do rio Tepuetini, de onde continuavam a hostilizar os colonos, e outros desceram ao vale do rio Marañón. Os próprios Omaguas da missão de San Joaquín referiam ao padre Maroni que os guerreiros de Tepuetini eram seus parentes, "en especial los que llaman Jetes [Yetés]" (Maroni, 1988 [1738]: 220).

143 D. Joseph González, gobernador de la Prov.a de Quixos y Macas, informa sobre las invasiones que padezen los pueblos christianos de su jurisdicción, Archidona, 8 de janeiro de 1722, AGI, Quito, leg. 137, n. ${ }^{\circ}$ 33, f. 296v.

144 El gobernador de la Provincia de Quijos y Macas, Joseph González, al rey, Macas, 17 de março de 1722, minuta do físcal do Conselho das Índias, AGI, Quito, leg. 137, n. ${ }^{\circ} 32$, f. 290 . 
com pormenores os inconvenientes de acabar com as encomiendas em uma região que alegava estar sobre constante ameaça de índios "gentiles y enemigos". As encomiendas não eram concedidas "por otra cosa, que para tener en unas provincias tan desiertas y vastas de montañas de muy notable asperezas promptos a los encomenderos con sus armas y gente"; só assim podiam resistir às "frequentes invasiones que hacen los indios enemigos y gentiles, siendo el premio de esta prontitud y continuos peligros que padecen, más del decoro que la utilidad de las encomiendas". ${ }^{145}$

No início do século XVIII, nessas regiões de fronteira, as encomiendas continuavam a ser concedidas "hasta por tres vidas" e "por servicios prestados en tierras de infieles". ${ }^{146}$ Entre 1724 e 1725, várias incursões promovidas pelos índios "bárbaros" nas jurisdições de Maynas, Quijos e Macas obrigaram a Audiência de Quito a reunir uma Junta de Guerra com os governadores dessas províncias. Para contar com o apoio dos índios que serviam em encomiendas, concordaram em moderar pela metade o tributo que deviam. Os encomenderos foram instados a participar pessoalmente das entradas, e caso não pudessem fazê-lo, que enviassem escudeiros bem providos de armas, petrechos e o mais necessário. Decidiram, ainda, recomendar aos franciscanos que possuíam missões em terras próximas às dos índios independentes que mantivessem em boa ordem a conversão e a educação dos seus neófitos. ${ }^{147}$

\section{CONSIDERAÇÕES FINAIS}

O presente estudo procurou mostrar que os índios amazônicos, durante boa parte dos séculos XVI e XVII, foram classificados por colonos e missionários em duas grandes categorias. De um lado, estavam os tidos por "amigos", em quem os espanhóis verificavam certos sinais de "polícia", a exemplo da existência de chefias e do uso de roupas; de outro, os "bárbaros", geralmente retratados como gente andeja e comedora de carne humana. Essas descrições correspondiam menos a uma situação real do que aos projetos específicos dos colonos e dos padres, vale dizer, a captura de mão de obra para o serviço pessoal e o estabelecimento de reduções. Mesmo as notícias de riquezas minerais que se supunha existiriam nas terras baixas encontravam-se atreladas aos estereótipos com que eram descritos certos grupos indígenas, de modo que a Amazônia se mostrava um El Dorado não tanto de riquezas ocultas,

\footnotetext{
145 Ibidem, f. 291.

146 Porras, 1987: 38.

147 Junta de Guerra, Quito, 24 de dezembro de 1725, AGI, Quito, leg. 131, n. ${ }^{\circ}$ 9, f. 2.
} 
mas sim de um contingente populacional que podia servir aos empreendimentos coloniais de fronteira.

$\mathrm{O}$ presente trabalho pretendeu somar-se a estudos recentes que têm repensado a influência do mito e do fantástico nas ações dos colonos e missionários espanhóis nas fronteiras do império. Uma análise minuciosa de uma série de informes permite perceber que o recurso às imagens improvisadas e oportunistas a respeito dos índios e da paisagem, inclusive com a retomada do mito do El Dorado, não era produto da credulidade e da falta de senso de realidade de conquistadores e missionários. Eram elementos discursivos com que esses agentes adentravam a um duro processo de negociação com as autoridades reais, com o que pretendiam obter, dentre outras coisas, auxílio para a realização de expedições; autorização e recursos para fundar missões; mercês de governação de vastos territórios, com a jurisdição necessária para encomendar os nativos; a inviolabilidade e mesmo a extensão das atuais encomiendas. Imagens que visavam estabelecer conexões persuasivas entre as aventuras propostas na região considerada e os interesses dominantes da Coroa espanhola. E embora os "índios de papel" apresentassem, quando cotejados os textos, características tão contraditórias e incoerentes, nem por isso se deve subestimar a importância dessas "descrições" que, ao fim e ao cabo, orientavam as políticas de controle territorial que incidiam sobre as populações amazônicas.

\section{REFERÊNCIAS BIBLIOGRÁFICAS}

Acosta, José de, S.J., De Procuranda Indorum Salute [1588], Madrid, España misionera, 1952.

Acosta, José de, S.J., Historia natural y moral de las Indias [1590], Madrid, CSIC, 2008.

Acuña, Cristóbal de, S.J., Nuevo descubrimiento del Gran Río de las Amazonas [1641], Madrid, Iberoamericana, 2009.

Agnolin, Adone, $O$ apetite da antropologia: o sabor antropofágico do saber antropológico: alteridade e identidade no caso Tupinambá, São Paulo, Humanitas, 2005.

Anda Aguirre, Alfonso, Primeros gobernadores de Mainas: los generales Vaca de Vega, Quito, Abya-Yala, 1995.

Andrien, Kenneth J., The kingdom of Quito, 1690-1830: the state and regional development, Cambridge/New York, Cambridge University Press, 1995. 
Baciero, Carlos, "Juan de Solórzano Pereira y la defensa del indio en América", Hispania Sacra, LVIII/117 (Madrid, 2006): 263-327.

Baczko, Bronislaw, Les imaginaires sociaux: mémoires et espoirs collectifs, Paris, Payot, 1984.

Bartra, Roger, El salvaje en el espejo, Barcelona, Destino, 1996.

Bayle, Constantino, S.J., El Dorado fantasma, Madrid, Consejo de la Hispanidad, $1943,2 .^{\mathrm{a}}$ ed.

Bernheimer, Richard, Wild men in the Middle Ages: a study in art, sentiment, and demonology, New York, Octagon Books, 1970.

Borja Gómez, Jaime Humberto, Los indios medievales de fray Pedro de Aguado: construcción del idólatra y escritura de la historia en una crónica del siglo XVI, Bogotá, Centro Editorial Javeriano, 2002.

Borja Gómez, Jaime Humberto, "Idolatría, tiranía y barbarie: la construcción del indígena en una crónica indiana", Scarlett O'Phelan Godoy e Carmen Salazar-Soler (eds.), Passeurs, mediadores culturales y agentes de la primera globalización en el mundo ibérico: siglos XVI-XIX, Lima, Pontificia Universidad Católica del Perú, 2005: 33-57.

Cardoso, Alírio, Maranhão na Monarquia Hispânica: intercâmbios, guerra e navegação nas fronteiras das Índias de Castela (1580-1655), tesis doctoral, Salamanca, Universidad de Salamanca, 2012.

Carvajal, Gaspar de et al., La aventura del Amazonas, Madrid, Historia 16, 1986.

Casas, Bartolomé de las, O.P., Apologética historia sumaria [1559], 2 tomos, México, Univ. Nacional Autónoma de México, Instituto de Investigaciones Históricas, 1967.

Certeau, Michel de, La fable mystique: XVIe-XVIIe siècle, Paris, Gallimard, 1982.

Chantre y Herrera, José, S.J., Historia de las misiones de la Compañia de Jesús en el Marañón español: 1637-1767 [ant. a 1801], Madrid, Impr. de A. Avrial, 1901.

Chartier, Roger, "Le monde comme représentation", Annales. Économies, Sociétés, Civilisations, XLIV/6 (Paris, 1989): 1505-1520.

Chartier, Roger, A história cultural: entre práticas e representações, Rio de Janeiro, Bertrand Brasil, 1990.

Chaumeil, Jean-Pierre e Fraysse-Chaumeil, Josette, “'La Canela y El Dorado’: Les indigènes du Napo et du Haut-Amazone - au XVIe siècle", Bulletin de l'Institut Français d'Études Andines, X/3-4 (Lima, 1981): 55-86.

Cipolletti, María Susana, "Jesuitas y Tucanos en el noroeste Amazónico del siglo XVIII: una armonía imposible”, Sandra Negro e Manuel M. Marzal, S.J. (eds.), Un reino en la frontera: las misiones jesuitas en la América colonial, Lima, Pontificia Universidad Católica del Perú, 1999: 223-241. 
Coello de la Rosa, Alexandre, Barro de Cristo: entre la Corona y el Evangelio en el Perú virreinal, 1568-1580, Barcelona, Universitat Autònoma, Servei de Publicacions, 2000.

Covarrubias Orozco, Sebastián de, Tesoro de la lengua castellana o española, Madrid, por Luis Sanchez, 1611.

Davin, Diego (ed.), Cartas edificantes, y curiosas, escritas de las missiones estrangeras, y de levante por algunos missioneros de la Compañia de Jesus, vol. 16, Madrid, En la Imprenta de la viuda de Manuel Fernandez, 1757.

Duviols, Pierre, La destrucción de las religiones andinas: conquista y colonia, México, Universidad Nacional Autónoma de México, 1977.

Elliott, John H., "Philip IV of Spain: prisoner of ceremony", A. G. Dickens (ed.), The Courts of Europe: politics, patronage, and royalty 1400-1800, New York, McGraw-Hill, 1977: 169-189.

Espinoza Soriano, Waldemar, Amazonía del Perú: historia de la gobernación y comandancia general de Maynas, Lima, Fondo Editorial del Congreso del Perú, 2007.

Estenssoro Fuchs, Juan C., Del paganismo a la santidad: la incorporación de los indios del Perú al Catolicismo (1532-1750), Lima, IFEA, 2003.

Fernández de Oviedo y Valdés, Gonzalo, Historia general y natural de las Indias. Tomo 4, Tercera Parte [1548], Madrid, Imprenta de la Real Academia de la Historia, 1855.

Figueroa, Francisco de, S.J., Relación de las misiones de la Compañía de Jesús en el país de los Maynas [1661], Madrid, Victoriano Suárez, 1904.

Gandía, Enrique de, Historia crítica de los mitos y leyendas de la conquista americana, Buenos Aires, Centro Difusor del Libro, 1946.

Gerbi, Antonello, La naturaleza de las Indias nuevas: de Cristóbal Colón a Gonzalo Fernández de Oviedo, México, FCE, 1978.

Gil, Juan, Mitos y Utopías del Descubrimiento. Tomo 3: El Dorado, Madrid, Alianza, 1989.

Giudicelli, Christophe, Guerre, identités et métissages aux frontières de l'Empire: la guerre des Tepehuán en Nouvelle Biscaye (1616-1619), thèse docteur de l'Univ. de Paris III, Sorbonne Nouvelle, 2001.

Giudicelli, Christophe, “¿'Naciones’ de enemigos? La identificación de los indios rebeldes en la Nueva Vizcaya (siglo XVII)", Salvador Bernabéu Albert (ed.), El Gran Norte Mexicano: indios, misioneros y pobladores entre el mito y la historia, Sevilla, CSIC, 2009: 27-66. 
Gómez González, Sebastián, Frontera selvática: españoles, portugueses y su disputa por el noroccidente amazónico, siglo XVIII, Bogotá, Instituto Colombiano de Antropología e Historia, 2014.

González Echevarría, Roberto, "Humanismo, retórica y las crónicas de la conquista", Alejo Carpentier e Roberto González de Echevarría (eds.), Historia y ficción en la narrativa hispanoamericana: coloquio de Yale, Caracas, Monte Ávila, 1984: 149-166.

Gutiérrez, Ramón A., When Jesus came, the Corn Mothers went away: marriage, sexuality, and power in New Mexico, 1500-1846, Stanford, Stanford University Press, 1991.

Hartog, François, $O$ espelho de Heródoto: ensaio sobre a representação do outro, Belo Horizonte, Ed. UFMG, 1999.

Hausberger, Bernd, "La violencia en la conquista espiritual: las misiones jesuitas de Sonora", Jahrbuch für Geschichte Lateinamerikas, XXX (Colônia, 1993): 27-54.

Hemming, John, The search for El Dorado, New York, Dutton, 1979.

Heriarte, Mauricio de, "Descrição do Estado do Maranhão, Pará, Corupá e Rio das Amazonas" [1662], N. Papavero et al. (eds.), O Novo Eden, Belém, Museu Paraense Emílio Goeldi, 2000: 221-237.

Herrera y Tordesillas, Antonio de, Historia general de los hechos de los castellanos en las islas y tierra firme del mar océano. Volumen 5. Década 5 [1615], Madrid, Francisco Martinez Abad, 1728.

Holanda, Sérgio B. de, Visão do Paraíso: os motivos edênicos no descobrimento e colonização do Brasil, São Paulo, Brasiliense, 2000.

Informes de jesuitas en el Amazonas, 1660-1684, Iquitos, Perú, IIAP-CETA, 1986.

Jauss, Hans R., La literatura como provocación, Barcelona, Península, 1976.

Jouanen, José, S.J., Historia de la Compañía de Jesús en la antigua provincia de Quito: 1570-1773, vol. 1, Quito, Ecuatoriana, 1941.

Jouanen, José, S.J., Historia de la Compañia de Jesús en la antigua provincia de Quito: 1570-1773, vol. 2, Quito, Ecuatoriana, 1943.

Kagan, Richard L. e Marías, Fernando, Imágenes urbanas del mundo hispánico: 1493-1780, Madrid, Iberdrola, 1998.

Lane, Kris E., Quito 1599: city and colony in transition, Albuquerque, University of New Mexico Press, 2002.

Laureano de la Cruz, O.F.M., "Nuevo descubrimiento del río de Marañón, llamado de las Amazonas, hecho por la religión de San Francisco, año 1651" [Madrid, 1653], Marcellino da Civezza, O.F.M. (ed.), Saggio di bibliografia geografica storica etnografica sanfrancescana, Prato, R. Guasti, 1879: 268-300. 
Lechner, Juan, “El concepto de 'policía' y su presencia en la obra de los primeros historiadores de Indias", Revista de Indias, XLI/165-166 (Madrid, 1981): 395-409.

Lestringant, Frank, Cannibals: the discovery and representation of the cannibal from Columbus to Jules Verne, Berkeley, University of California Press, 1997.

Levaggi, Abelardo, Diplomacia Hispano-Indígena en las fronteras de América: historia de los tratados entre la Monarquía española y las comunidades aborígenes, Madrid, Centro de Estudios Políticos y Constitucionales, 2002.

Livi Bacci, Massimo, El Dorado en el pantano: oro, esclavos y almas entre los Andes y la Amazonia, Madrid, Marcial Pons, 2012.

López Ruiz, Jesús M., "Primer plan español para cubrir la Línea de Tordesillas", El Tratado de Tordesillas y su proyección, vol. 1, Valladolid, Universidad de Valladolid, Seminario de Historia de América, 1973: 357-383.

Lorandi, Ana María, De quimeras, rebeliones y utopías: la gesta del inca Pedro Bohorques, Lima, Pontificia Universidad Católica del Perú, 1997.

MacCormack, Sabine, Religion in the Andes: vision and imagination in early colonial Peru, Princeton, N.J., Princeton University Press, 1991.

MacCormack, Sabine, "Limits of understanding: perceptions of Greco-Roman and Amerindian Paganism in Early Modern Europe", K. O. Kupperman (ed.), America in European consciousness, 1493-1750, Chapel Hill, University of North Carolina Press, 1995: 79-129.

Magnin, Juan, S.J., Descripción de la Provincia y misiones de Mainas en el Reino de Quito [1740], Quito, Biblioteca Ecuatoriana "Aurelio Espinosa Pólit", 1998.

Maldavsky, Aliocha, Vocaciones inciertas: misión y misioneros en la provincia jesuita del Perú en los siglos XVI y XVII, Sevilla, CSIC, 2012.

Maroni, Pablo, S.J., Noticias auténticas del famoso río Marañón y misión apostólica de la Compañía de Jesús [1738], Iquitos, Perú, CETA, 1988.

Mignolo, Walter D., "El metatexto historiografico y la historiografia Indiana", MLN, Hispanic Issue, XCVI/2 (Baltimore, 1981): 358-402.

Monteiro, John M., Negros da terra: índios e bandeirantes nas origens de São Paulo, São Paulo, Companhia das Letras, 1994.

Monteiro, John M., Tupis, tapuias e historiadores: estudos de história indígena e do indigenismo, tese livre-docência, Universidade Estadual de Campinas (Brasil), 2001.

Newson, Linda A., Life and death in early colonial Ecuador, Norma, University of Oklahoma Press, 1995.

Oberem, Udo, Los Quijos: historia de la transculturación de un grupo indígena en el Oriente Ecuatoriano, Otavalo, Ecuador, Instituto Otavaleño de Antropología, 1980 . 
Oberem, Udo, "Un grupo indigena desaparecido del oriente ecuatoriano", S. Moreno Yanez e U. Oberem (eds.), Contribución a la etnohistoria ecuatoriana, Otavalo, Equador, Instituto Otavaleño de Antropología, 1981: 355-389.

Ortiguera, Toribio de, "Jornada del Río Maranón" [1586], E. Mampel González e N. Escandell Tur (eds.), Lope de Aguirre: Crónicas, 1559-1561, Barcelona, Editorial 7 1/2, 1981: 32-174.

Ortiz de la Tabla Ducasse, Javier, Los encomenderos de Quito, 1534-1660: origen y evolución de una elite colonial, Sevilla, Escuela de Estudios Hispano-Americanos, 1993.

Pagden, Anthony, La caída del hombre: el indio americano y los orígenes de la etnología comparativa, Madrid, Alianza, 1988.

Pino Díaz, Fermín del, "Los caníbales chiriguanos, un reto etnográfico para dos mentes europeas: Acosta y Polo", Fermín Díaz del Pino e C. Lázaro (eds.), Visión de los otros y visión de sí mismos: ¿descubrimiento o invención entre el Nuevo Mundo y el Viejo?, Madrid, CSIC, 1995: 57-88.

Porras, María E., Gobernación y Obispado de Mainas: siglos XVII y XVIII, Quito, Abya-Yala, 1987.

Raminelli, Ronald, Imagens da colonização: a representação do índio de Caminha a Vieira, Rio de Janeiro, Zahar, 1996.

Ramos Pérez, Demetrio, El Mito del Dorado: su génesis y proceso, Caracas, Academia Nacional de la Historia, 1973.

Real Academia Española, Diccionario de Autoridades. Diccionario de la lengua castellana en que se explica el verdadero sentido de las voces, su naturaleza y calidad, con las phrases o modos de hablar, los proverbios o rephranes, y otras cosas convenientes al uso de la lengua, 6 vols., Madrid, En la Imprenta de Francisco del Hierro, 1726-1739.

Renard-Casevitz, France M., Saignes, Th. e Taylor, A. C., Al este de los Andes: relaciones entre las sociedades amazónicas y andinas entre los siglos XV y XVII, Quito, Abya-Yala, 1988.

Rey Fajardo, José del, S.J., "Las escoltas militares en las misiones jesuíticas de la Orinoquia, 1661-1767", Boletín de la Academia Nacional de la Historia, LXXVIII/311 (Caracas, 1995): 35-69.

Rodríguez, Manuel, S.J., El descubrimiento del Marañón [1684], Madrid, Alianza, 1990.

Rumazo González, José, La región amazónica del Ecuador en el siglo XVI, Sevilla, Escuela de Estudios Hispano-Americanos, 1946.

Scott, Heidi V., Contested territory: mapping Peru in the sixteenth and seventeenth centuries, Notre Dame, University of Notre Dame Press, 2009. 
Simón, Pedro, O.F.M., Noticias historiales de las conquistas de Tierra Firme en las Indias Occidentales. Volumen 2. Segunda Parte, "Tercera Noticia” [c. 1627], Bogotá, Medardo Rivas, 1891.

Solano, Francisco de, Ciudades hispanoamericanas y pueblos de indios, Madrid, CSIC, 1990.

Solórzano Pereira, Juan de, Política indiana [1648], 3 tomos, Madrid, Biblioteca Castro, 1996.

Taylor, Anne C., "The western margins of Amazonia from the early sixteenth to the early nineteenth century", F. Salomon e S. B. Schwartz (eds.), The Cambridge history of the native peoples of the Americas: vol. 3, part 2, South America, Cambridge, Cambridge University Press, 1999: 188-256.

Ugarte, Auxiliomar S., Sertões de bárbaros: o mundo natural e as sociedades indígenas da Amazônia na visão dos cronistas ibéricos (séculos XVI-XVII), Manaus, Valer, 2009.

Valadés, Diego, O.F.M., Retórica cristiana [1579], México, FCE, 1989.

Vitar, Beatriz, "Mansos y salvajes: imágenes chaqueñas en el discurso colonial”. F. de Pino Díaz e C. Lázaro (eds.), Visión de los otros y visión de sí mismos: ¿descubrimiento o invención entre el Nuevo Mundo y el Viejo?, Madrid, CSIC, 1995: 107-126.

Fecha de recepción: 27 de abril de 2016.

Fecha de aceptación: 23 de junio de 2016.

\title{
Images of Indians in Sixteenth- and Seventeenth-Century Spanish Amazonia
}

\begin{abstract}
From the mid-sixteenth century and throughout the seventeenth century, settlers and missionaries assiduously explored the fringes of Amazonia located east of the Audience of Quito. In that period, they circulated several images of native peoples. Indians were classified into two broad categories: on the one hand, those in whom the Spanish established some signs of "polity" were perceived as "friends"; while, on the other the "barbarians" were usually depicted as nomads and cannibals. A more systematic analysis of these images shows that they were congruent with settlers' and missionaries' specific goals: the capture of Indians for personal service and the establishment of missions.
\end{abstract}

KeY WORDs: friendly Indians; barbarous Indians; Amazonia; Jesuit missions; encomienda. 